Canadian

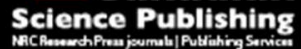

Canadian Journal of Physiology and Pharmacology Revue canadienne de physiologie et pharmacologie

\title{
Sequential analysis and staging of a diethylnitrosamine induced hepatocellular carcinoma in male Wistar albino rat model
}

\begin{tabular}{|r|l|}
\hline Journal: & Canadian Journal of Physiology and Pharmacology \\
\hline Manuscript ID & cjpp-2017-0413.R1 \\
\hline Manuscript Type: & Article \\
\hline Date Submitted by the Author: & 05-Jul-2017 \\
\hline Complete List of Authors: & $\begin{array}{l}\text { Fathy, Abdallah; Al-Azhar University Faculty of Science, Zoology } \\
\text { Bashandy, Mohamad; Al-Azhar University Faculty of Science, Zoology } \\
\text { bashandy, samir; National Research Center, Pharmacology } \\
\text { Mansour, Ahmed; Al-Azhar University, Pharmacology } \\
\text { Elsadek, Bakheet; Faculty of Pharmacy, Al-Azhar University, Assiut Branch, } \\
\text { Assiut, Egypt, Department of Biochemistry and Molecular Biology }\end{array}$ \\
\hline $\begin{array}{r}\text { Is the invited manuscript for } \\
\text { consideration in a Special } \\
\text { Issue?: }\end{array}$ & N/A \\
\hline Keyword: & $\begin{array}{l}\text { Hepatocarcinogenesis; tumor markers; staging system; oxidative stress; } \\
\text { hematology; lipid profile. }\end{array}$ \\
\hline &
\end{tabular}




\section{Sequential analysis and staging of a diethylnitrosamine induced hepatocellular carcinoma in male Wistar albino rat model}

Abdallah H. Fathy ${ }^{1}$, Mohamed A. Bashandy ${ }^{1}$, Samir AE. Bashandy ${ }^{2}$, Ahmed M. Mansour ${ }^{3}$, Bakheet Elsadek ${ }^{4}$

${ }^{1}$ Department of Zoology, Faculty of Science, Al-Azhar University, Cairo, Egypt.

${ }^{2}$ Department of Pharmacology, National Research Center, Cairo, Egypt.

${ }^{3}$ Department of Pharmacology and Toxicology, Faculty of Pharmacy, Al-Azhar University, Cairo, Egypt.

${ }^{4}$ Department of Biochemistry and Molecular Biology, Faculty of Pharmacy, Al-Azhar University, Assiut, Egypt.

\section{Corresponding Author:}

Abdallah H. Fathy, Zoology Department, Faculty of Science, Al-Azhar University, Nasr City, Cairo, Egypt. Postal code 11651.

Email: abdallahhfathy@pharma.asu.edu.eg // abdallah.ahf@Gmail.com

\section{Tel.: (002) 01146194141}

\section{E-mails of co-authors:}

drbashandy@hotmail.com

bashandys@hotmail.com

dr.ahmedmmansour@yahoo.com

bakheet.elkot@azhar.edu.eg
(Prof. Dr. Mohamed A. Bashandy)

(Prof. Dr. Samir AE Bashandy)

(Prof. Dr. Ahmed M. Mansour)

(Dr. Bakheet Elsadek) 


\begin{abstract}
Hepatocellular carcinoma (HCC) is one of the most life-threatening cancers. The present study was designed to chronologically analyze the HCC chemically induced by diethylnitrosamine (DEN) in male Wistar rats during 27 weeks. DEN was given to rats in drinking water $(100 \mathrm{mg} / \mathrm{L})$ to induce HCC. In the present study, the DEN administered groups recorded dramatic results in the tumor markers, oxidative stress, lipid profile, liver function and hematological parameters at all intervals when compared to their corresponding values in the control groups. In addition, the morphometric analysis of livers of the DEN administered groups (from 9 to 27 weeks) showed gradual enlargement and several grayish white nodules and foci on the peripheral surface of the liver as the features of HCC. In conclusion, the present sequential model chronologically analyzes all steps of hepatocarcinogenesis and presents new staging system for classification of HCC that may be valuable for investigating the effects of anti-carcinogenic compounds at varying stages of hepatocarcinogenesis in vivo.
\end{abstract}

Keywords: DEN; Hepatocarcinogenesis; tumor markers; staging system; oxidative stress; hematology; lipid profile. 


\section{Introduction}

The primary liver cancer or hepatocellular carcinoma (HCC) is the fifth most common cancer and is the second most common cause of cancer mortality worldwide (Ferlay et al. 2014 and Stewart \& Wild 2014). It also disproportionately influences males, with HCC the second leading cause of cancer mortality in men and the ninth leading cause of women (Lozano et al. 2012).

Nitrosamines are compounds formed by the combination of amines and nitrates or nitrites. Studies have shown that nitrosamines can be formed in the human stomach by a process commonly referred to as endogenous nitrosation. The bacteria in the mouth chemically reduce nitrate found in many vegetables to nitrite, which in turn can form nitrosating agents. Many foods that contain amines can react with these nitrosating agents in the acidic environment of the stomach to form nitrosamines (Jakszyn and Gonzalez 2006). Diethylnitrosamine (DEN) is a representative chemical of a family of carcinogenic N-nitroso compounds and well-known hepatocarcinogen; forming DNA adducts in the liver and inducing HCC (Singer and Crunderger 1984).

DEN is reasonably anticipated to be a human carcinogen based on sufficient evidence of carcinogenicity in experimental animals (IARC 1987). The routes of human exposure to DEN are ingestion, inhalation and dermal contact. There is some potential for occupational exposure of laboratory, copolymer, lubricant and pesticide workers. The general population may possibly be exposed to unknown quantities of DEN present in preserved foods, beverages, tobacco smoke, herbicides, pesticides, drinking water and industrial pollution (Tricker \& Preussmann 1991). The present study analyzed and staged the HCC induced by DEN in rats. 


\section{Materials and methods}

\section{Chemicals}

Diethylnitrosamine was purchased from Sigma-Aldrich (St. Louis, MO, USA). DEN was given to rats in drinking water $(100 \mathrm{mg} / \mathrm{L})$. The DEN solution was prepared as a fresh solution every other day and administered to rats in dark bottles. Other chemicals and reagents were of high analytical grade and were purchased from standard commercial suppliers.

\section{Experimental animals}

A patch of 240 adult mature male Wistar albino rats obtained from the Egyptian Holding Company for Biological Products and Vaccines (VACSERA, Giza, Egypt) averaged weight $150-170 \mathrm{~g}$ were allowed to acclimatize in the laboratory and distributed into 16 groups of 15 rats each (8 control groups and 8 DEN administered groups) as demonstrated in Fig. (1). Rats were maintained under standard laboratory conditions at the animal center, Faculty of Pharmacy, Al-Azhar University, Cairo, Egypt. They were kept in a temperature-controlled environment $\left(20-25^{\circ} \mathrm{C}\right)$ and $45 \%-55 \%$ relative humidity with an alternating $12 \mathrm{~h}$ light-dark cycle. Five rats were placed into each cage and provided with standard diet pellets and drinking DEN or tap water ad libitum.

\section{Ethics statement}

The in vivo animal experiments were conducted in accordance with the Guide for the Care and Use of Laboratory Animals (National Research Council 1996) and the use of animals was reviewed and approved by an independent ethics committee of the National 
Research Centre in Egypt. Samples were collected from each animal under anesthesia and all efforts were made to minimize suffering.

\section{Collection of samples}

At the end of the experiment, blood samples were collected from each animal from the retro-orbital venous plexus puncture. One part of the blood was collected in EDTA tubes for hematological study. The other part of the blood was left to clot at room temperature for 15 minutes. Sera were separated by centrifugation at $3000 \mathrm{rpm}$ at $20^{\circ} \mathrm{C}$ for 15 minutes where the clear serum was obtained and kept frozen at $-80^{\circ} \mathrm{C}$ for various biochemical analyses. After blood sampling, animals were sacrificed and livers were isolated and washed with isotonic ice-cold saline, dried on filter paper and weighed immediately.

\section{Morphometric analysis}

The nodules in nodule-bearing livers were counted and classified into three categories according to size; the nodular size in millimeter was measured by the use of an official standard caliper.

\section{Biochemical study}

A portion of each animal liver tissue was taken from all animal groups. Each tissue was homogenized in ice-cold Tris- $\mathrm{HCl}$ lysis buffer, $\mathrm{pH} 7.4$ containing $1 \%$ protease inhibitor cocktail (Cell Signaling Technology, Inc., MA, USA) using Potter-Elvehjem rotor-stator Homogenizer, fitted with a Teflon pestle (Omni International, Kennesaw, GA, USA). The tissue homogenates were centrifuged under cooling at $3000 \mathrm{rpm}$ for 20 min., supernatants were subsequently aliquoted and stored at $-80^{\circ} \mathrm{C}$ until used for determination of hepatic oxidative stress parameters. 


\section{Hepatic oxidative stress parameters}

Lipid peroxidation product (TBARS) (Yoshioka et al. 1979), Advanced oxidation protein products (AOPPs) (Witko-Sarsat et al. 1996), nitric oxide (NO) (Montgomery and Dymock 1961), reduced glutathione (GSH) (Beutler et al. 1963), superoxide dismutase (SOD) (Minami and Yoshikawa 1979) and catalase (CAT) (Aebi 1984) levels were estimated using kits from bio-diagnostic Co., for research kits, Egypt.

\section{Liver function tests}

The serum levels of transaminases, AST and ALT (Bergmeyer et al. 1986), alkaline phosphatase (ALP) (the German Society for Clinical Chemistry 1972), total protein (TP) (Gornal et al. 1949), albumin (Doumas et al. 1971), and total bilirubin (TBIL) (Scherwin and Thompson 2003) were estimated using kits from Elitech diagnostic Co., France. The globulin was determined by subtracting the albumin from the TP for each rat.

\section{Lipid profile}

The serum lipid profile levels of triglycerides (TG) (Fossati and Principe 1982), total cholesterol (TC) (Allain et al. 1974) and high-density lipoprotein cholesterol (HDL-C) (Burstein et al. 1970) were estimated using kits from Elitech diagnostic Co., France. (LDL-C) was calculated according to the formula of Wieland and Seidel (1982).

\section{Serum tumor markers}

Serum gamma-glutamyl transferase $(\gamma-\mathrm{GT})$ (Szasz 1969) activity was determined kinetically (Elitech diagnostic Co. France). Serum alpha-L-fucosidase (AFU) (WUHAN EIAAB SCIENCE CO., LTD., CHINA), alpha-fetoprotein (AFP) (LifeSpan BioSciences, 
Inc. Seattle, WA, USA), AFP-L3 (Alpha-Fetoprotein Lens Culinaris Agglutinin 3) (Elabscience Biotechnology Co., Ltd. Wuhan, China), glypican-3 (GPC3) (LifeSpan BioSciences, Inc. Seattle, WA, USA), Golgi protein 73 (GP73) (MyBioSource, Inc. San Diego, USA), Serum vascular endothelial growth factor (VEGF) (LifeSpan BioSciences, Inc. Seattle, WA, USA) levels were assayed by ELISA technique.

\section{Hematological parameters}

The erythrocyte count, total and differential leukocyte count, platelet count, hematocrite percentage, and hemoglobin concentration were estimated in the blood by using a CBC analyzer (Sino thinker. sk9000, U.S).

\section{Western blot assessments}

The Western blot assessments of glypican-3 and Golgi protein 73 were conducted according to the procedure described by Elsadek et al. (2017).

\section{Statistical analysis}

The statistical analysis of the results was performed by using statistical package for social sciences SPSS/PC computer program (version 19). All values were expressed as mean $\pm \mathrm{SE}$ and the results were analyzed using one-way analysis of variance (ANOVA) test followed by least significant difference (LSD) test for multiple comparisons. Differences were considered statistically significant at $\mathrm{p}<0.05$. 


\section{Results}

\section{The body weight and the mortality rate}

The change in body weight during the period of the experiment ( 27 weeks) in the control and diethylnitrosamine (DEN) administered groups illustrated in Fig. (2) and demonstrated that, in the first weeks following DEN administration, the rats began to show a slow growth and along with the DEN administration, the mean weight decreased gradually as compared to the control rats. The marked decrease in body weight was recorded start from week 12 to week 18 of DEN administration. The body weight became nearly steady with no marked changes from week 18 to the end of the experiment. The present study showed no mortality in the control groups during the experiment (27 weeks). On the other hand, the mortality rate of DEN administered groups was $0 \%, 0 \%$, $6.67 \%, 13.33 \%, 20.00 \%, 33.33 \%, 46.67 \%$ and $60.00 \%$ during $6,9,12,15,18,21,24$ and 27 weeks, respectively.

\section{The liver weight}

The DEN administered groups at all intervals recorded a significant decrease $(p<0.05)$ of the final body weight and body weight gain when compared to their corresponding values in the control groups. On the contrary, a significant increase $(p<0.05)$ in liver weight and relative liver weight were recorded at all DEN administered intervals except for the interval of 6 weeks, which recorded a significant decrease $(p<0.05)$ when compared to their corresponding values in the control groups (Table 1). 


\section{Morphometric analysis of the liver}

The morphometric analysis of the liver in the control groups reveals smooth surface with normal morphology, without any sub capsular nodules through the 27-week experimental period. Similarly, the livers in the DEN administered group at the end of 6 weeks also, appeared with smooth surface without any nodules. On the contrary, the macroscopic gross appearance of livers in the DEN administered groups (from 9 to 27 weeks interval) showing gradual enlargement and several grayish white nodules and foci on the peripheral surface of the liver as the features of HCC (Fig. 3).

The incidence of nodules in DEN administered groups were zero $\%, 30 \%, 70 \%, 80 \%$ at the end of 6, 9, 12 and 15 weeks, respectively, and 100\% at the end of 18, 21, 24 and 27 weeks. The average number of nodules at nodule-bearing liver in DEN administered groups showed an insignificant increase at the first three time points $(6,9$ and 12 weeks) as compared to each others. On the other hand, the other five time points $(15,18,21,24$ and 27 weeks) recorded a significant increase $(p<0.05)$ in the average number of nodules at nodule-bearing livers when compared to each others in an ascending manner and as any of them being compared to any of the first three time points (Table 1). In the present study, the number of nodules with size less than $1 \mathrm{~mm}$ in diameter at nodule-bearing liver in DEN administered groups recorded a significant increase $(p<0.05)$ in an ascending manner. Moreover, the time points 18, 21, 24 and 27 weeks recorded a significant increase $(p<0.05)$ in the number of hypoplastic nodules with size from $1-3 \mathrm{~mm}$ in diameter at nodule-bearing livers when compared to each others in an ascending manner. Furthermore, the time points 21, 24 and 27 weeks recorded a significant increase $(\mathrm{p}<0.05)$ in the number of hyperplastic (neoplastic) nodules with size more than $3 \mathrm{~mm}$ in 
diameter at nodule-bearing livers when compared to each others in an ascending manner (Table 1).

\section{Oxidative stress parameters}

The DEN administered groups recorded a significant increase $(p<0.05)$ in TBARS and AOPPs throughout the experimental period when compared to their corresponding control values, except for the TBARS at the 6 weeks it recorded insignificant change as compared to the corresponding value in the control group. In addition, the DEN administered groups recorded a significant decrease $(\mathrm{p}<0.05)$ in NO, SOD, CAT and GSH at the end of $6,9,12,15,18,21,24$ and 27 weeks respectively, when compared to their corresponding values in the control groups (Table 2).

\section{Liver function tests}

The DEN administered groups recorded a significant increase $(\mathrm{p}<0.05)$ in AST, ALT, ALP, TBIL, TP \& globulin in contrast to a significant decrease $(\mathrm{p}<0.05)$ in albumin \& $\mathrm{A} / \mathrm{G}$ ratio at the end of $6,9,12,15,18,21,24$ and 27 weeks respectively, when compared to their corresponding values in the control groups. Except for TBIL at 6 weeks, it recorded an insignificant increase as compared to the corresponding control value (Table 3).

\section{Hepatocellular carcinoma tumor markers}

The DEN administered groups recorded a significant increase $(p<0.001)$ in GGT, AFU, AFP, AFP-L3 \& GP73 at the end of 6, 9, 12, 15, 18, 21, 24 and 27 weeks respectively, in DEN administered groups when compared to their corresponding values 
in the control groups. In addition, the DEN administered groups recorded an insignificant increase in GPC3 in the first four time intervals $(6,9,12 \& 15$ weeks) and a significant increase $(\mathrm{p}<0.001)$ throughout the remaining experimental periods $(18,21,25 \& 27$ weeks) when compared to their corresponding control values. However, the DEN administered groups recorded an insignificant increase in VEGF in the first two time intervals $(6 \& 9$ weeks $)$ and a significant increase $(\mathrm{p}<0.001)$ throughout the remaining experimental periods $(12,15,18,21,24 \& 27$ weeks) when compared to their corresponding control values (Table 4 and Fig. 4). Moreover, the DEN administered groups recorded over-expressions of GPC3 and GP73 in the liver tissue homogenates as indicated by the Western blot assessments (Fig. 5).

\section{Lipid profile}

The DEN administered groups recorded a significant increase $(\mathrm{p}<0.05)$ in $\mathrm{TG}, \mathrm{TC}$, LDL-C, TG/HDL-C, TC/HDL-C \& LDL-C/HDL-C risk ratios and a significant decrease $(p<0.05)$ in HDL-C at the end of $6,9,12,15,18,21,24$ and 27 weeks respectively when compared to their corresponding values in the control groups (Table 5).

\section{Hematological parameters}

The DEN administered groups recorded a significant decrease $(\mathrm{p}<0.05)$ in the $\mathrm{RBC}$ count, $\mathrm{Hb}$ concentration, Hct percentage, platelet count, WBC count and lymphocyte percentage at the end of $6,9,12,15,18,21,24$ and 27 weeks respectively, when compared to their corresponding control values. Except for lymphocyte percentage at 6 weeks, it recorded insignificant change as compared to the corresponding values in the control groups. On the other hand, the DEN administered groups recorded a significant 
increase $(p<0.05)$ in neutrophil percentage and monocyte percentage at the end of 6,9 , $12,15,18,21,24$ and 27 weeks, respectively, when compared to their corresponding control values, except for the neutrophils percentage at 6 weeks and monocytes percentage at 6 and 9 weeks they recorded insignificant change as compared to the corresponding values in the control groups (Table 6).

\section{Hepatocelluar carcinoma staging}

Bashandy, Mansour \& Fathy (BMF) staging system in the present study includes an assessment of liver disease (HCC) and tumor extension through physical, oxidative stress, hematological, biochemical and specific tumor marker parameters for HCC following treatment with DEN. The BMF staging system might be an appropriate classification system for HCC induced in rat model using diethylnitrosamine. In addition, based on the intensive investigation of the current data, the BMF staging system is classified into an early (6-12 weeks), intermediate (15-18 weeks), advanced (18-21 weeks) and late stages $(24-27$ weeks $)$ of the disease. All stages recorded a significance difference $(p<0.05)$ in all tested parameters from each other's and as any of them being compared to the control rats. The notable feature of the BMF staging system is the assignment of treatment recommendations for each stage based on the best treatment options currently available, and this system has been updated according to the results of our investigations that have incorporated strong evidence. The BMF staging system and treatment allocations are summarized in (Table 7). 


\section{Discussion}

Hepatocellular carcinoma is a highly heterogeneous disease with highly variable etiological factors, including viruses with a DNA (HBV) or RNA (HCV) genome, chemicals (diethylnitrosamine and aflatoxins), and inborn and acquired metabolic diseases. In addition, HCC undergoes a dynamic process changing morphological features as it advances. Therefore, mechanisms of hepatocellular carcinogenesis may vary depending on different factors. The most prominent ones including loss of cell cycle control, escape from senescence control, resistance to cell death, phenotypic plasticity, motility, invasion, and metastasis (Brian 2016).

A correlation was noted between the raised incidence of HCC and obesity. Overweight and obese individuals had an increased risk of developing HCC (Clark et al. 2006). It was determined that the non-alcoholic fatty liver disease (NAFLD) is related to obesity, diabetes and metabolic syndrome (MS) (Scalera and Tarantino 2014). NAFLD, the abnormal accumulation of fat in the liver is the strict clinical and patho-physiological links with obesity, insulin resistance and type 2 diabetes mellitus (T2DM) have led to the suggestion that NAFLD can be considered a new criterion of MS (Tarantino and Finelli 2003). An increased risk of developing HCC was demonstrated not only in T2DM patients, but also in obese subjects and those with the criteria of MS (Duan et al. 2013). The relationships between T2DM, MS and HCC seem to be closely related to NAFLD development. The majority of obese patients or those with MS develop NAFLD (Neuschwander-Tetri and Caldwell 2003). The increased incidence of $\mathrm{HCC}$ in obese and diabetic animals has led to the necessity to characterize the role of MS in liver carcinogenesis (Obara et al. 2017). Glucose intolerance, hyperglycemia, T2DM, obesity, 
hypertension and dyslipidemia are the key components in MS (Scalera and Tarantino 2014).

Chemicals like diethylnitrosamine (DEN) contribute to cancer development. In agreement with the present study, perturbations in single cells lead to the focal outgrowth of putatively preneoplastic lesions. The altered areas can evolve into nodular hyperplasia, focus in nodule pathology and areas of malignancy (Rochen and Carl-McGrath 2001). Since the liver is the primary site for cancer induction in the bioassays used for carcinogen testing, there is a need for extrapolation of animal neoplasms that arise at this site to man. The utility of defining common biomarkers for the conversion of benign to malignant transition will assist in developing appropriate interspecies extrapolation as demonstrated in the present work. In light of the present investigated tumor markers, several studies have combined various biomarkers and in general, shown improved detection performance (Hadziyannis et al. 2013; Wang et al. 2013; Johnson et al. 2014).

In view of our data, the identification of a carcinogenic potential for an agent delineates the conditions of exposure (dose, time and duration) under which the agent may induce cancer. Animals are surrogate models of humans since they possess similar physiology and biochemistry. Several factors are important for cancer development, including a loss of normal growth control as recorded in the present study with contributions from inhibition of apoptosis and enhanced, but altered proliferation control (Hanahan and Weinberg 2011). 
Various researchers confirmed that the attenuation of tumor expansion via natural products (Pradeep et al. 2007; Jagan et al. 2008). Few of researchers observed that the decreased content of nutrition might be connected with reduced tumor volume. Recently, it has been proven that caloric restriction protocols and restricted feeding schedules are protective in experimental carcinogenic animal models and the time-caloric restriction prevents fibrosis from progressing into cirrhosis, thus avoiding chronic inflammation and regenerative processes. It also prevents, probably through circadian entrainment and caloric restriction, the neoplastic transformation of tumoural lesions induced by diethylnitrosamine (Molina-Aguilar et al. 2017).

Various studies proved that there is a low content of the reactive oxygen species (ROS), during the normal cell physiological progression. Several factors are directly responsible for increasing the ROS production and affect the cellular macromolecules (nucleic acid, protein and lipids) as environmental factors, carcinogenesis and stressful conditions (Ghosh et al. 2012).

Diethylnitrosamine (DEN) is a representative chemical carcinogen with the potential to cause tumors in various organs, including the liver, skin, gastrointestinal tract, kidney and respiratory system (IARC, 1987). Specifically DEN has been widely used to induce experimental hepatocellular carcinoma (Brian 2016). Chemical carcinogenesis is strongly associated with the formation of ROS. Consequently, excessive generation of oxygen-derived radicals stimulates the oncogenesis via modulation of the redox signal pathways. ROS also generates the cell death via DNA fragmentation, lipid peroxidation and protein oxidation (Bishayee et al. 2010). 
In agreement with the present study, oxidative stress can be considered a key event in the progression from fatty liver to steatohepatitis. An increase in the production of ROS and RNS, mainly derived from mitochondrial free fatty acids oxidation, leading to dyslipidemia and increased supply of free fatty acids to the liver that combined with increased de novo lipogenesis determines an abnormal intrahepatic triglyceride accumulation (Tarantino et al. 2011; Salomone et al. 2013). The absence of efficient endogenous scavenging activity like in the present study, leads to increased levels of free radicals which may trigger hepatocyte injury and activation of inflammatory and fibrogenic signaling in the liver (Gambino et al. 2011).

The unconjugated bilirubin is a metabolic end product of heme breakdown into the reticular-endothelial system (Ryter et al. 2006). Several experimental evidences suggest that the unconjugated bilirubin is the main endogenous lipid antioxidant and is cytoprotective in different tissues and organs (Stocker 2004; Salomone et al. 2013). Stocker et al (1987) first recognized the antioxidant effect of bilirubin in an in vitro experiment showing that bilirubin is able to scavenge peroxyl radicals in liposomes even more efficiently than alpha-tocopherol, the best characterized molecule counteracting lipid peroxidation. Consistently, the unconjugated bilirubin suppresses the oxidation of lipids and lipoproteins, especially LDL cholesterol (Wu et al. 1996).

The lipid peroxidation products are considered as the classical marker of oxidative stress. Several incidences confirmed the possible mechanism for damage of the red blood corpuscle in lipid peroxidation, which is generally induced by the free radicals. DENadministered rats in the present work demonstrated high levels of liver enzymes (AST \& ALT) and augmented content of total bilirubin and ALP in serum; all are considered as 
the hepatic toxicity markers. The high concentration of total bilirubin in the present study may attributed to the high conjugated bilirubin which confirmed the increased degradation rate of red blood cells, while modulation of ALP content directly showed the pathological changes in biliary flow (Zhao et al. 2015).

During the oxidative stress, constant generation of oxygen radicals reacts with the unstable fatty acids and forms products such as peroxy fatty acid radical and the produced radical continues to react with another free radical and forms the unpredictable chain of lipid peroxide. Altered lipid profile in malignant tissue like in the present work is the critical parameter, due to an effect on the fluidity, membrane integrity and circulation cellular process, which is directly related to the cell survival and growth (Tarantino et

\section{al. 2011; Thangavel and Vaiyapuri 2013).}

In light of the present work, during the DEN-induced carcinogenesis, the lipid peroxidation products (TBARS) such as 4-hydroxy nominal and MDA react with the various free radicals and initiate the oxidative stress, which causes the carcinogenic effect (Bansal et al. 2005; Verma et al. 2017). The increased content of the lipid peroxidation products (TBARS) and protein oxidation products (AOPPs) during DEN administration in the present study provoked the generation of free radicals, which confirmed by reduced oxidative stress markers of enzymatic endogenous antioxidant (SOD \& CAT), nonenzymatic antioxidant (GSH) and nitric oxide (NO) concentrations.

In line with the present work, spontaneous liver cancer in both humans and animals occurs predominantly in males. Early studies on rodents exposed to carcinogens indicated that male rodents are more likely to develop liver tumors and the incidence in males 
being marginally greater in the Wistar strain (McKillop et al. 2006). In liver cancer research with experimental animals, DEN is used either as a complete carcinogen or as an initiator in multistage models. When used as a tumor initiator, DEN is usually given as a single dose of $200 \mathrm{mg} / \mathrm{kg}$ to induce pronounced liver necrosis and presumably certain gene mutations in some hepatocytes (Goldsworthy and Hanigan 1986). When used as a complete carcinogen as in the present study, DEN is usually given for several weeks (Elsadek et al. 2017). The sequential administration of DEN for several weeks has been demonstrated to induce HCC in rodents (Chuang et al. 2000).

Liver cancer induction and progression has been extensively examined in the rodent. The induction process represented by a population of initiating hepatocytes in the rat liver and this is true for several types of genotoxic carcinogens including diethylnitrosamine in a dose dependent manner of administration that results in the formation of bulky DNA adducts (Saeter et al. 1989). Some subset of these cells will grow into colonies of hepatocytes and by the definition of some of those that will progress into hepatic neoplastic nodules and HCC (Dragan et al. 1994). The promotion stage of cancer development has been operationally defined as the clonal expansion of the initiated cell population (Saeter et al. 1989). The stage of progression encompasses the spectrum of changes that occur in the conversion of preneoplastic cells into malignant neoplasia (Pitot 2007). In agreement with the present work, morphologically, the focus in nodule configuration is the earliest endpoint for detection of progression in the liver (Pitot 2007;

\section{Zhao et al. 2013).}

Because of the high recurrence rate and poor prognosis, the prognostic assessment and selection of treatment strategy in HCC patients are quite important and a precise 
stratification system for the prognosis of HCC patients is required (Llovet et al. 2004; Llovet et al. 2008). In patients with HCC, the prediction of prognosis is complex compared with most solid tumors. It is well known that the prognosis and treatment of HCC depend on the tumor burden in addition to patient's underlying liver disease and liver functional reserve (Bruix \& Sherman 2011). Therefore, staging systems based on information regarding both tumor factors and host factors such as liver function has been required to accurately classify HCC patients undergoing various therapeutic options (Duseja 2014; Kinoshita et al. 2015). Staging systems aim to direct patients to different treatment arms, ensuring optimal utilization of resources. Different staging systems and survival prediction models have been suggested for HCC, mainly to ensure appropriate treatment allocation. The most widely used in human is the Barcelona Cancer Liver Clinic (BCLC) staging system (Pons et al. 2005; Bruix \& Sherman 2011).

In the present study the Bashandy, Mansour \& Fathy (BMF) staging system for HCC induced in rat model using DEN is in agreement with the BCLC staging system in human in that, it links staging with treatment modalities and with an estimation of the mortality rates. It identifies early $\mathrm{HCC}$ that may benefit from curative therapies and provide excellent long-term survival, those at intermediate or advanced disease stage that may benefit from treatment therapies, as well as those at the end stage with a very poor life expectancy. Other staging systems are less frequently used. Some offer only clinical staging with no prognostic value while others are very population specific and not applicable to all HCC patients. The BMF staging system developed based on the combination of data from several parameters representing different disease stages. It includes variables related to tumor stage and liver functional status. 
Various chemo-protective and epidemiologic investigations already proved that the regular intake of fruit and vegetable has been reducing the risk factor of cancer in animal and in human. Several shreds of evidence have accentuated that biologically active products present in functional food may be exploited as a complementary treatment for hepatic cancer (Butler 2008; Verma et al. 2017).

Compounds that have potential chemopreventive and therapeutic effects on the liver and working by different mechanisms include acyclic retinoid (ACR), capsaicin, caffeine, cinnamaldehyde, curcumin, diallyl sulfide (DAS), eicosapentaenoic acid (EPA), epigallocatechin-3-gallate (EGCG), genistein, resveratrol, lycopene, sulforaphane (SFN) and silymarin (Okano et al. 2011). In addition, various forms of the foods and drinks confirm the presence of triterpenoids which have been recently scrutinized as a potential treatment of various inflammatory and cancer disease through down-regulation of the oxidative stress, inflammation and pathology via NF-kB pathway (Verma et al. 2017).

The HCC model using DEN and the BMF staging system may be utilized for investigating the beneficial effects of anti-carcinogenic compounds and for the compounds used for the treatment of $\mathrm{HCC}$ in vivo and may be valuable for investigating the effects of compounds at varying stages of hepatocarcinogenesis. 


\section{References}

Aebi H. 1984. Catalase in vitro methods in enzymology (Ed. B. J. Willam) Academic press, New Yourk, ABD; p.121-126. PMID:6727660.

Allain C C, Poon L S, Chan C S G, Richmond W, Fu P C. 1974. Enzymatic determination of total serum cholesterol. Clin. Chem. 20: 470-475. PMID: 4818200 .

Bansal A, Bansal M, Soni G, Bhatnagar D. 2005. Modulation of N-nitrosodiethylamine (NDEA) induced oxidative stress by vitamin E in rat erythrocytes. Hum Exp Toxicol 24: 297-302. PMID:16004196; doi:10.1191/0960327105ht533oa.

Bergmeyer H U, Horder M, Rej R. 1986. IFCC method for aspartate aminotransferase. J. Clin. Chem. Clin. Biochem. 24: 497. PMID:3734712.

Beutler E, Duron O, Kelly B. 1963. Improved method for the determination of blood glutathione. J. Lab. and Clin. Med. 61(5): 882-888. PMID:13967893.

Bishayee A, Barnes K F, Bhatia D, Darvesh A S, Carroll R T. 2010. Resveratrol suppresses oxidative stress and inflammatory response in diethylnitrosamineinitiated rat hepatocarcinogenesis. Cancer prevention research 3(6): 753-763. doi: 10.1158/1940-6207.CAPR-09-0171.

Brian I C. 2016. Hepatocellular Carcinoma Diagnosis and Treatment. Third edition ed. Springer. doi:10.1007/978-3-319-34214-6.

Bruix J, Sherman M. 2011. Management of hepatocellular carcinoma:an update. Hepatology 53(3): 1020-1022. PMID:21374666; PMCID:PMC3084991; doi: 10.1002/hep.24199.

Burstein M, Scholnick H R, Morfin R. 1970. Rapid method for the isolation of lipoprotein from human serum by precipitation with polyanions. Journal of Lipid Research 11: 583-595. PMID:4100998. 
Butler M S. 2008. Natural products to drugs: natural product-derived compounds in clinical trials. Natural product reports 25(3): 475-516. doi:10.1039/b514294f.

Chuang S, Kuo M, Hsu C, Chen C, Lin J, Lai G, Hsieh C, Cheng A. 2000. Curcumincontaining diet inhibits diethylnitrosamine-induced murine hepatocarcinogenesis. Carcinogenesis 21: 331-335. PMID:10657978.

Clark J M. 2006. The epidemiology of nonalcoholic fatty liver disease in adults. Journal of clinical gastroenterology 40: S5-S10. PMID:16540768.

Doumas B T, Watson W A, Biggs H G. 1971. Albumin standards and the measurement of serum albmin with bromocresol green. Clin. Chem. Acta. 31: 87-96. PMID: 5544065 .

Dragan Y, Hully J, Nakamura J, Mass M, Swenberg J, Pitot H. 1994. Biochemical events during initiation of rat hepatocarcinogenesis. Carcinogenesis. 5: 1451-1458. PMID:8033324.

Duan X F, Tang P, Li Q, Yu Z T. 2013. Obesity, adipokines and hepatocellular carcinoma. International journal of cancer 133(8): 1776-1783. doi: 10.1002/ijc. 28105 .

Duseja A. 2014. Staging of hepatocellular carcinoma. J Clin Exp Hepatol. 4(3): S74-79. PMCID: PMC4284240; doi:10.1016/j.jceh.2014.03.045.

Elsadek B, Mansour A, Saleem T, Warnecke A, Kratz F. 2017. The antitumor activity of a lactosaminated albumin conjugate of doxorubicin in a chemically induced hepatocellular carcinoma rat model compared to sorafenib. Digestive and Liver Disease 49(2): 213-222. http://dx.doi.org/10.1016/j.dld.2016.10.003.

Ferlay J, Soerjomataram I, Ervik M, Dikshit R, Eser S, Mathers C, et al. 2014. GLOBOCAN 2012: cancer incidence and mortality, version 1.1. IARC Cancer Baseed. Lyon: IARC.

Fossati P, Prencipe L. 1982. Serum triglycerides determined colorimetrically with an enzyme that produces hydrogen peroxide. Clin. Chem. Acta 28: 2077-2080. 
http://publications.iarc.fr/Databases/Iarc-Cancerbases/Globocan-2012-EstimatedCancer-Incidence-Mortality-And-Prevalence-Worldwide-In-2012-V1-0-2012. .

Gambino R, Musso G, Cassader M. 2011. Redox balance in the pathogenesis of nonalcoholic fatty liver disease: mechanisms and therapeutic opportunities. $\begin{array}{lllll}\text { Antioxidants } & \& & \text { redox } & \text { signaling } & \mathbf{1 5}(5):\end{array}$ https://doi.org/10.1089/ars.2009.3058.

German Society for Clinical Chemistry. 1972. Standard method for determination of alkaline phosphatase (AP) activity. J. Clin.Chem. Clin. Biochem. 10: 290. http://edoc.hu-berlin.de/oa/degruyter/cclm.1992.30.4.247.pdf.

Ghosh D, Choudhury S T, Ghosh S, Mandal A K, Sarkar S, Ghosh A, Saha K D, Das N. 2012. Nanocapsulated curcumin: oral chemopreventive formulation against diethylnitrosamine induced hepatocellular carcinoma in rat. Chemico-biological interactions 195(3): 206-214. doi:10.1016/j.cbi.2011.12.004.

Goldsworthy T, Hanigan M. 1986. Models of hepatocarcinogenesis in the rat-contrasts and comparisons. CRC Crit Rev Toxicol 17: 61-89. PMID:3527567 doi: $10.3109 / 10408448609037071$.

Gornal A C, Bardwill C J, David M M. 1949. Determination of serum proteins by means of the biuret reaction. J. Biol. Chem. 177: 751-766. PMID:18110453.

Hadziyannis E, Sialevris K, Georgiou A, Koskinas J. 2013. Analysis of serum afetoprotein-L3 \% and des-c carboxyprothrombin markers in cases with misleading hepatocellular carcinoma total a-fetoprotein levels. Oncol. Rep. 29: 835-839. https://doi.org/10.3892/or.2012.2147.

Hanahan D, Weinberg R. 2011. The hallmarks of cancer: the next generation. Cell 144(5): 646-674. PMID:21376230 doi:10.1016/j.cell.2011.02.013.

IARC. 1987. Overall Evaluations of Carcinogenicity. IARC Monographs on the Evaluation of Carcinogenic Risk of Chemicals to Humans. Lyon, France: International Agency for Research on Cancer 7: 440. 
http://monographs.iarc.fr/ENG/Monographs/suppl7/Suppl7.pdf.

Institute of Laboratory Animal Resources. 1996. Guide for the Care and Use of Laboratory Animals, eighth edition. Committee for the update of the guide and use of laboratory animals. National research council of the national academies.National Academy Press. Washington, D.C.

Jagan S, Ramakrishnan G, Anandakumar P, Kamaraj S, Devaki T. 2008. Antiproliferative potential of gallic acid against diethylnitrosamine-induced rat hepatocellular carcinoma. Molecular and cellular biochemistry 319(1): 51-59. doi: 10.1007/s11010-008-9876-4.

Jakszyn P, Gonzalez C. 2006. Nitrosamine and related food intake and gastric and oesophageal cancer risk: a systematic review of the epidemiological evidence. World J Gastroenterol 21: 4296-4303. doi:10.3748/wjg.v12.i27.4296; PMCID: PMC4087738.

Johnson P, Pirrie S, Cox T, Berhane S, Teng M, Palmer D, Morse J, Hull D, Patman G, Kagebayashi C. 2014. The detection of hepatocellular carcinoma using a prospectively developed and validated model based on serological biomarkers. Cancer Epidemiol Biomarkers Prev. 23: 144-153. doi:10.1158/1055-9965; PMID: 24220911.

Kinoshita A, Onoda H, Fushiya N, Koike K, Nishino H, Tajiri H. 2015. Staging systems for hepatocellular carcinoma: current status and future perspectives. World $\mathrm{J}$ Hepatol. 7(3): 406-424. doi:10.4254/wjh.v7.i3.406; PMCID:PMC4381166.

Llovet J, Fuster J, Bruix J. 2004. The Barcelona approach: diagnosis, staging, and treatment of hepatocellular carcinoma. Liver Transpl 10(2 Suppl 1): S115-S120. PMID:14762851; doi:10.1002/lt.20034.

Llovet J, Ricci S, Mazzaferro V, Hilgard P, Gane E, Blanc J. 2008. Sorafenib in advanced hepatocellular carcinoma. N Engl J Med. 359(4): 378-390. PMID:18650514 doi: 10.1056/NEJMoa0708857. 
Lozano R, Naghavi M, Foreman K, Lim S, Shibuya K, Aboyans V, et al. 2012. Global and regional mortality from 235 causes of death for 20 age groups in 1990 and 2010: a systematic analysis for the Global Burden of Disease Study 2010. Lancet 380(9859): 2095-2128. PMID: 23245604; doi:10.1016/S0140-6736(12)61728-0.

McKillop I, Moran D, Jin X, Koniaris L. 2006. Molecular pathogenesis of hepatocellular carcinoma. J. Surg. Res. 136: 125-135. PMID:17023002 doi: 10.1016/j.jss.2006.04.013.

Minami M, Yoshikawa H. 1979. A simplified assay method of superoxide dismutase activity for clinical use. Clinica. Chim. Acta. 92: 337-342. PMID:436274.

Molina-Aguilar C, de Jesús Guerrero-Carrillo M, Espinosa-Aguirre J J, Olguin-Reyes S, Castro-Belio T, Vázquez-Martínez O, Rivera-Zavala J B, Díaz-Muñoz M. 2017. Time caloric restriction inhibits the neoplastic transformation of cirrhotic liver in rats treated with diethylnitrosamine. Carcinogenesis: bgx052. doi: https://doi.org/10.1093/carcin/bgx052.

Montgomery H A, Dymock J F. 1961. The determination of nitrite in water. Analyst 86: 414-416.

Neuschwander-Tetri B A, Caldwell S H. 2003. Nonalcoholic steatohepatitis: summary of an AASLD Single Topic Conference. Hepatology 37(5): 1202-1219. PMID: 12717402 .

Obara K, Shirakami Y, Maruta A, Ideta T, Miyazaki T, Kochi T, Sakai H, Tanaka T, Seishima M, Shimizu M. 2017. Preventive effects of the sodium glucose cotransporter 2 inhibitor tofogliflozin on diethylnitrosamine-induced liver tumorigenesis in obese and diabetic mice. Oncotarget. doi: 10.18632/oncotarget.16874.

Okano J-i, Fujise Y, Abe R, Imamoto R, Murawaki Y. 2011. Chemoprevention against hepatocellular carcinoma. Clinical journal of gastroenterology 4(4): 185-197. doi: 10.1007/s12328-011-0227-8. 
Pitot H. 2007. Adventures in hepatocarcinogenesis. Annu. Rev. Pathol. 2: 1-29. PMID: 18039091 doi:10.1146/annurev.pathol.2.010506.092027.

Pons F, Varela M, Llovet J. 2005. Staging systems in hepatocellular carcinoma. HPB (Oxford) 7(1): 35-41. PMID:18333159; PMCID:PMC2023920; doi: $10.1080 / 13651820410024058$.

Pradeep K, Mohan C V R, Gobianand K, Karthikeyan S. 2007. Silymarin modulates the oxidant-antioxidant imbalance during diethylnitrosamine induced oxidative stress in rats. European journal of pharmacology 560(2): 110-116. doi: 10.1016/j.ejphar.2006.12.023.

Rochen C, Carl-McGrath S. 2001. Pathology and pathogenesis of hepatocellular carcinomas. Dig Dis 19: 269-278. PMID:11935086; doi:50693.

Ryter S W, Alam J, Choi A M. 2006. Heme oxygenase-1/carbon monoxide: from basic science to therapeutic applications. Physiological Reviews 86(2): 583-650. doi: 10.1152/physrev.00011.2005.

Saeter G, Schwarze P, Nesland J, Seglen P. 1989. Diploid nature of hepatocellular tumours developing from transplanted preneoplastic liver cells. Br. J. Cancer. 59(2): 198-205. PMID:2930686; PMCID:PMC2247004.

Salomone F, Li Volti G, Rosso C, Grosso G, Bugianesi E. 2013. Unconjugated bilirubin, a potent endogenous antioxidant, is decreased in patients with non-alcoholic steatohepatitis and advanced fibrosis. Journal of gastroenterology and hepatology 28(7): 1202-1208. DOI:10.1111/jgh.12155.

Scalera A, Tarantino G. 2014. Could metabolic syndrome lead to hepatocarcinoma via non-alcoholic fatty liver disease? World journal of gastroenterology: WJG 20(28): 9217. doi:10.3748/wjg.v20.i28.9217.

Scherwin J E, Thompson C. 2003. Liver function. Clinical Chemistry: Theory, Analysis, Correlation, 4th Ed., Kaplan, L.A, Pesce, A.J., Kazmierczak, S.C., (Mosby Inc. eds St Louis USA). 493 and appendix. http://trove.nla.gov.au/version/45636328. 
Singer B, Crunderger D. 1984. Molecular Biology, Mutagens and Carcinogens. Plenum Press, New York: 127. PMCID:PMC1976845.

Stewart B, Wild C. 2014. International Agency for Research on Cancer: World Cancer Report. ISBN-13 (Print Book): 978-92-832-0429-9.

Stocker R. 2004. Antioxidant activities of bile pigments. Antioxidants \& redox signaling 6(5): 841-849. https://doi.org/10.1089/ars.2004.6.841.

Stocker R, Yamamoto Y, McDonagh A F, Glazer A N, Ames B N. 1987. Bilirubin is an antioxidant of possible physiological importance. Science 235: 1043-1047. PMID: 3029864.

Szasz G. 1969. Kinetic photometric method for srum gamma glutamyltranspeptidase. Clin. Chem. 15(124). PMID:5773262.

Tarantino G, Colao A, Capone D, Conca P, Tarantino M, Grimaldi E, Chianese D, Finelli C, Contaldo F, Scopacasa F. 2011. Circulating levels of cytochrome C, gammaglutamyl transferase, triglycerides and unconjugated bilirubin in overweight/obese patients with non-alcoholic fatty liver disease. Journal of biological regulators and homeostatic agents 25(1): 47-56. PMID:21382273.

Tarantino G, Finelli C. 2013. What about non-alcoholic fatty liver disease as a new criterion to define metabolic syndrome? World journal of gastroenterology: WJG 19(22): 3375. DOI: 10.3748/wjg.v19.i22.3375.

Thangavel P, Vaiyapuri M. 2013. Antiproliferative and apoptotic effects of naringin on diethylnitrosamine induced hepatocellular carcinoma in rats. Biomedicine \& Aging Pathology 3(2): 59-64. doi:10.1016/j.biomag.2013.01.006.

Tricker A, Preussmann R. 1991. Carcinogenic N- nitrosamines in the diet: occurrence, formation, mechanisms and carcinogenic potential. Mutat Res 259: 277-289. PMID:2017213.

Verma A, Singh D, Anwar F, Bhatt P C, Al-Abbasi F, Kumar V. 2017. Triterpenoids principle of Wedelia calendulacea attenuated diethynitrosamine-induced 
hepatocellular carcinoma via down-regulating oxidative stress, inflammation and pathology via NF-kB pathway. Inflammopharmacology. doi:10.1007/s10787-0170350-3.

Wang M, Mehta A, Block T, Marrero J, di Bisceglie A, Devarajan K A. 2013. omparison of statistical methods for the detection of hepatocellular carcinoma based on serum biomarkers and clinical variables. BMC Med Genom. 6: 9.

Wieland H, Seidel D. 1982. Improved assessment of plasma lipoprotein patterns.IV. Simple preparation of a lyophilized control serum containing intact human plasma lipoproteins. Clin. Chem. 28: 1335-1337. PMID:7074941.

Witko-Sarsat V, Friedlander M, Capeillere-Blandin C, Nguyen-Khoa T, Nguyen A T, Zingraff J, Jungers P, Deschamps-Latscha B. 1996. Advanced oxidation protein products as a novel marker of oxidative stress in uraemia. Kidney Int. 49: 13041313. PMID:8731095.

Wu T-W, Fung K, Wu J, Yang C-C, Weisel R D. 1996. Antioxidation of human low density lipoprotein by unconjugated and conjugated bilirubins. Biochemical pharmacology 51(6): 859-862. https://doi.org/10.1016/0006-2952(95)02395-X.

Yoshioka T, Kawada K, Shimada T, Mori M. 1979. Lipid peroxidation in maternal and cord blood and protective mechanism against activated-oxygen toxicity in the blood. J. obstet. Gynecol. 135: 372-376. PMID:484629.

Zhao X, Chen Q, Li Y, Tang H, Liu W, Yang X. 2015. Doxorubicin and curcumin codelivery by lipid nanoparticles for enhanced treatment of diethylnitrosamineinduced hepatocellular carcinoma in mice. European Journal of Pharmaceutics and Biopharmaceutics 93: 27-36. doi:10.1016/j.ejpb.2015.03.003.

Zhao Y-J, JU Q, LI G-C. 2013. Tumor markers for hepatocellular carcinoma (Review). MOLECULAR AND CLINICAL ONCOLOGY 1: 593-598. PMID:24649215; PMCID:PMC3915636; DOI: 10.3892/mco.2013.119. 


\section{Legends}

Fig. (1): The experimental schedules of diethylnitrosamine (DEN) administered and control (C) groups during 27 weeks.

Fig. (2): The chronological changes of body weight during 27 weeks in the control and diethylnitrosamine (DEN) administered groups.

Fig. (3): The macroscopic gross appearance of livers at the end of the experimental periods in the control and DEN administered groups (Arrows indicate nodules).

Fig (4): percentage of AFP-L3 (Lens culinaris agglutinin-reactive fraction of AFP) to total AFP at the end of the experimental periods in the control and DEN administered groups.

Fig (5): Western blot analysis of GPC3 (A) and GP73 (B) expressions in liver tissues at the end of experimental periods in the control and DEN administered groups. 
Table (1): The physical parameters of the DEN and control groups.

\begin{tabular}{|c|c|c|c|c|c|c|c|c|c|c|c|c|c|}
\hline \multirow{2}{*}{$\mathbf{W}$} & \multirow{2}{*}{ Groups } & \multirow{2}{*}{$\begin{array}{c}\text { Final } \\
\text { body wt. } \\
\text { (g) }\end{array}$} & \multirow{2}{*}{$\begin{array}{l}\text { Gain in } \\
\text { body wt. } \\
\text { (g) }\end{array}$} & \multirow{2}{*}{$\begin{array}{l}\text { Liver Wt. } \\
\text { (g) }\end{array}$} & \multirow{2}{*}{$\begin{array}{l}\text { Relative } \\
\text { liver Wt. } \\
\text { (g) }\end{array}$} & \multirow{2}{*}{$\begin{array}{c}\text { Nodule } \\
\text { incidence } \\
\%\end{array}$} & \multirow{2}{*}{$\begin{array}{c}\text { Average no. } \\
\text { of nodules/ } \\
\text { nodule } \\
\text { bearing } \\
\text { liver }\end{array}$} & \multicolumn{6}{|c|}{ Relative nodular size (\% of total numbers) } \\
\hline & & & & & & & & $<1 \mathrm{~mm}$ & $\%$ & 1-3 mm & $\%$ & $>3 \mathbf{m m}$ & $\%$ \\
\hline \multirow{2}{*}{6} & $\mathbf{C}$ & $261 \pm 1.56^{\mathrm{a}}$ & $97.3 \pm 2.80^{\mathbf{a}}$ & $6.54 \pm 0.07^{\mathrm{a}}$ & $2.49 \pm 0.01^{\mathbf{a b}}$ & 0 & $0 \pm 0^{\mathbf{a}}$ & $0 \pm 0^{\mathbf{a}}$ & 0.00 & $0 \pm 0^{\mathbf{a}}$ & 0.00 & $0 \pm 0^{\mathbf{a}}$ & 0.00 \\
\hline & DEN & $244 \pm 1.63^{\mathbf{b}}$ & $76.6 \pm 3.18^{\mathbf{b c}}$ & $5.84 \pm 0.12^{\mathrm{a}}$ & $2.39 \pm 0.05^{\mathbf{b}}$ & 0 & $0 \pm 0^{\mathbf{a}}$ & $0 \pm 0^{\mathbf{a}}$ & 0.00 & $0 \pm 0^{\mathbf{a}}$ & 0.00 & $0 \pm 0^{\mathbf{a}}$ & 0.00 \\
\hline \multirow{2}{*}{9} & $\mathbf{C}$ & $302 \pm 1.20^{\mathbf{c}}$ & $144 \pm 2.10^{\mathbf{d}}$ & $8.66 \pm 0.08^{\mathbf{b}}$ & $2.86 \pm 0.01^{\mathrm{a}}$ & 0 & $0 \pm 0^{\mathbf{a}}$ & $0 \pm 0^{\mathbf{a}}$ & 0.00 & $0 \pm 0^{\mathbf{a}}$ & 0.00 & $0 \pm 0^{\mathbf{a}}$ & 0.00 \\
\hline & DEN & $278 \pm 1.25^{\mathbf{d}}$ & $117 \pm 2.61^{\mathbf{e}}$ & $9.38 \pm 0.23^{\mathbf{b c}}$ & $3.36 \pm 0.08^{\mathbf{c}}$ & 30 & $1.2 \pm 0.62^{\mathbf{a}}$ & $1.2 \pm 0.62^{\mathbf{a b}}$ & 100.00 & $0 \pm 0^{\mathbf{a}}$ & 0.00 & $0 \pm 0^{\mathbf{a}}$ & 0.00 \\
\hline \multirow{2}{*}{12} & C & $347 \pm 0.90^{\mathbf{e}}$ & $188 \pm 2.31^{\mathbf{f}}$ & $9.73 \pm 0.03^{\mathbf{c}}$ & $2.80 \pm 0.00^{\mathrm{a}}$ & 0 & $0 \pm 0^{\mathrm{a}}$ & $0 \pm 0^{\mathbf{a}}$ & 0.00 & $0 \pm 0^{\mathbf{a}}$ & 0.00 & $0 \pm 0^{\mathbf{a}}$ & 0.00 \\
\hline & DEN & $306 \pm 1.02^{\mathbf{c}}$ & $145 \pm 1.78^{\mathbf{d}}$ & $12.22 \pm 0.20^{\text {d }}$ & $3.99 \pm 0.06^{\mathbf{d}}$ & 70 & $7.33 \pm 1.54^{\mathbf{a b}}$ & $5.2 \pm 1.21^{\mathbf{b}}$ & 78.79 & $1.4 \pm 0.45^{\mathbf{a b}}$ & 21.21 & $0 \pm 0^{\mathbf{a}}$ & 0.00 \\
\hline \multirow{2}{*}{15} & C & $384 \pm 1.18^{\mathbf{f}}$ & $217 \pm 1.78^{\mathbf{g}}$ & $10.76 \pm 0.04^{\mathbf{e}}$ & $2.80 \pm 0.01^{\mathbf{a}}$ & 0 & $0 \pm 0^{\mathbf{a}}$ & $0 \pm 0^{\mathbf{a}}$ & 0.00 & $0 \pm 0^{\mathbf{a}}$ & 0.00 & $0 \pm 0^{\mathbf{a}}$ & 0.00 \\
\hline & DEN & $323 \pm 1.36^{\mathbf{g}}$ & $162 \pm 1.30^{\mathbf{h}}$ & $14.82 \pm 0.66^{\mathbf{f}}$ & $4.57 \pm 0.18^{\mathbf{e}}$ & 80 & $17.2 \pm 3.31^{\mathbf{b}}$ & $11.4 \pm 2.10^{\mathrm{c}}$ & 66.28 & $4.9 \pm 1.08^{\mathbf{b}}$ & 28.49 & $0.9 \pm 0.23^{\mathbf{a}}$ & 5.23 \\
\hline \multirow{2}{*}{18} & C & $425 \pm 2.11^{\mathbf{h}}$ & $261 \pm 2.39^{\mathbf{i}}$ & $11.80 \pm 0.03^{\mathbf{d}}$ & $2.77 \pm 0.01^{\mathbf{a}}$ & 0 & $0 \pm 0^{\mathbf{a}}$ & $0 \pm 0^{\mathbf{a}}$ & 0.00 & $0 \pm 0^{\mathbf{a}}$ & 0.00 & $0 \pm 0^{\mathbf{a}}$ & 0.00 \\
\hline & DEN & $242 \pm 2.25^{\mathbf{b}}$ & $82.4 \pm 2.62^{\mathbf{c}}$ & $20.75 \pm 0.39^{\mathrm{g}}$ & $8.57 \pm 0.14^{\mathbf{f}}$ & 100 & $38.3 \pm 6.12^{\mathbf{c}}$ & $23.9 \pm 3.36^{\mathbf{d}}$ & 62.40 & $12.2 \pm 2.45^{\mathbf{c}}$ & 31.85 & $2.2 \pm 0.53^{\mathbf{a}}$ & 5.74 \\
\hline \multirow{2}{*}{21} & C & $473 \pm 1.62^{\mathbf{i}}$ & $312 \pm 2.30^{\mathbf{j}}$ & $12.92 \pm 0.03^{\mathbf{d}}$ & $2.72 \pm 0.00^{\mathbf{a b}}$ & 0 & $0 \pm 0^{\mathbf{a}}$ & $0 \pm 0^{\mathbf{a}}$ & 0.00 & $0 \pm 0^{\mathbf{a}}$ & 0.00 & $0 \pm 0^{\mathbf{a}}$ & 0.00 \\
\hline & DEN & $234 \pm 1.34^{\mathbf{j}}$ & $73.6 \pm 2.02^{\mathbf{b}}$ & $27.52 \pm 0.75^{\mathbf{h}}$ & $11.73 \pm 0.30^{\mathbf{g}}$ & 100 & $75 \pm 7.40^{d}$ & $37.7 \pm 3.45^{\mathbf{e}}$ & 50.27 & $25.3 \pm 3.10^{\mathrm{d}}$ & 33.73 & $12 \pm 1.17^{\mathbf{b}}$ & 16.00 \\
\hline \multirow{2}{*}{24} & C & $510 \pm 1.21^{\mathbf{k}}$ & $350 \pm 1.77^{\mathbf{k}}$ & $14.32 \pm 0.05^{\mathbf{f}}$ & $2.80 \pm 0.00^{\mathbf{a}}$ & 0 & $0 \pm 0^{\mathbf{a}}$ & $0 \pm 0^{\mathbf{a}}$ & 0.00 & $0 \pm 0^{\mathbf{a}}$ & 0.00 & $0 \pm 0^{\mathbf{a}}$ & 0.00 \\
\hline & DEN & $242 \pm 1.26^{\mathbf{b}}$ & $83.9 \pm 1.84^{\mathbf{c}}$ & $29.30 \pm 0.45^{\mathbf{i}}$ & $12.07 \pm 0.13^{\mathbf{g}}$ & 100 & $93.5 \pm 6.62^{\mathbf{e}}$ & $42.9 \pm 2.16^{\mathbf{f}}$ & 45.88 & $32.3 \pm 2.85^{\mathbf{e}}$ & 34.55 & $18.3 \pm 2.28^{\mathbf{c}}$ & 19.57 \\
\hline \multirow{2}{*}{27} & C & $529 \pm 1.08^{l}$ & $377 \pm 2.49^{1}$ & $14.85 \pm 0.05^{\mathbf{f}}$ & $2.80 \pm 0.00^{\mathrm{a}}$ & 0 & $0 \pm 0^{\mathbf{a}}$ & $0 \pm 0^{\mathbf{a}}$ & 0.00 & $0 \pm 0^{\mathbf{a}}$ & 0.00 & $0 \pm 0^{\mathbf{a}}$ & 0.00 \\
\hline & DEN & $234 \pm 1.13^{\mathbf{j}}$ & $72.8 \pm 1.99^{\mathbf{b}}$ & $30.31 \pm 0.63^{\mathbf{j}}$ & $12.91 \pm 0.30^{\mathbf{h}}$ & 100 & $114 . \pm 9.32^{\mathbf{f}}$ & $48.5 \pm 3.50^{\mathbf{g}}$ & 42.43 & $40.7 \pm 3.33^{\mathbf{f}}$ & 35.61 & $25.1 \pm 2.95^{\text {d }}$ & 21.96 \\
\hline
\end{tabular}

Results are expressed as mean \pm SE: standard error; Values not sharing common superscript are significant with each other at $\mathrm{p}<0.05$; W: weeks; C: control; DEN: diethylnitrosamine; wt: weight. 
Table (2): The oxidative stress markers in the liver tissue of the DEN and control groups.

\begin{tabular}{|c|c|c|c|c|c|c|c|}
\hline W & Groups & $\begin{array}{c}\text { TBARS } \\
\text { (nmole/g } \\
\text { tissue) }\end{array}$ & $\begin{array}{c}\text { AOPPs } \\
\text { nmole/g } \\
\text { tissue) }\end{array}$ & $\begin{array}{c}\text { NO } \\
(\mu \mathrm{mol} / \mathrm{g} \\
\text { tissue })\end{array}$ & $\begin{array}{l}\text { SOD } \\
\text { (U/mg } \\
\text { tissue) }\end{array}$ & $\begin{array}{l}\text { CAT } \\
\text { (U/mg } \\
\text { tissue) }\end{array}$ & $\begin{array}{l}\text { GSH } \\
\text { nmol/g } \\
\text { tissue) }\end{array}$ \\
\hline \multirow{2}{*}{6} & $\mathrm{C}$ & $194 \pm 1.08^{\mathbf{a}}$ & $195 \pm 0.94^{\mathrm{a}}$ & $40.96 \pm 0.48^{\mathbf{a}}$ & $74.32 \pm 1.20^{\mathrm{a}}$ & $1.55 \pm 0.01^{\mathrm{a}}$ & $2.94 \pm 0.01^{\mathrm{a}}$ \\
\hline & DEN & $197 \pm 0.98^{\mathbf{a}}$ & $200 \pm 0.78^{\mathbf{b}}$ & $37.21 \pm 0.62^{\mathbf{b}}$ & $69.26 \pm 1.38^{\mathbf{b}}$ & $1.32 \pm 0.04^{\mathbf{b}}$ & $2.33 \pm 0.01^{b}$ \\
\hline \multirow{2}{*}{9} & $\mathrm{C}$ & $193 \pm 0.96^{\mathbf{a}}$ & $194 \pm 0.61^{\mathrm{a}}$ & $41.29 \pm 0.77^{\mathbf{a}}$ & $74.59 \pm 1.40^{\mathrm{a}}$ & $1.54 \pm 0.01^{\mathrm{a}}$ & $2.96 \pm 0.02^{\mathrm{a}}$ \\
\hline & DEN & $214 \pm 1.51^{\mathbf{b}}$ & $219 \pm 1.78^{\mathbf{c}}$ & $34.68 \pm 0.60^{\mathbf{c}}$ & $64.24 \pm 1.47^{\mathbf{c}}$ & $1.11 \pm 0.02^{\mathbf{c}}$ & $2.18 \pm 0.01^{\mathbf{C}}$ \\
\hline \multirow{2}{*}{12} & C & $195 \pm 1.09^{\mathbf{a}}$ & $195 \pm 1.09^{\mathbf{a}}$ & $41.05 \pm 0.89^{\mathbf{a}}$ & $73.85 \pm 1.59^{\mathrm{a}}$ & $1.54 \pm 0.01^{\mathrm{a}}$ & $2.94 \pm 0.01^{\mathrm{a}}$ \\
\hline & DEN & $251 \pm 1.65^{\mathbf{c}}$ & $254 \pm 1.24^{\mathrm{d}}$ & $32.36 \pm 0.90^{d}$ & $59.86 \pm 1.67^{\mathrm{d}}$ & $0.97 \pm 0.02^{\mathrm{d}}$ & $2.03 \pm 0.01^{\mathrm{d}}$ \\
\hline \multirow{2}{*}{15} & C & $195 \pm 1.03^{\mathrm{a}}$ & $194 \pm 0.93^{\mathrm{a}}$ & $41.06 \pm 0.80^{\mathbf{a}}$ & $73.80 \pm 1.73^{\mathrm{a}}$ & $1.54 \pm 0.01^{\mathrm{a}}$ & $2.95 \pm 0.01^{\mathrm{a}}$ \\
\hline & DEN & $270 \pm 1.18^{d}$ & $275 \pm 1.05^{\mathrm{e}}$ & $25.99 \pm 0.92^{\mathrm{e}}$ & $54.88 \pm 1.43^{\mathrm{e}}$ & $0.87 \pm 0.01^{\mathbf{e}}$ & $1.94 \pm 0.01^{\mathrm{e}}$ \\
\hline \multirow{2}{*}{18} & $\mathbf{C}$ & $194 \pm 1.30^{\mathbf{a}}$ & $194 \pm 0.85^{\mathrm{a}}$ & $41.91 \pm 0.79^{\mathbf{a}}$ & $74.12 \pm 1.69^{\mathrm{a}}$ & $1.55 \pm 0.01^{\mathrm{a}}$ & $2.95 \pm 0.01^{\mathrm{a}}$ \\
\hline & DEN & $315 \pm 1.93^{\mathrm{e}}$ & $314 \pm 1.20^{\mathbf{f}}$ & $20.48 \pm 0.80^{\mathbf{f}}$ & $51.27 \pm 1.71^{\mathrm{e}}$ & $0.76 \pm 0.01^{\mathbf{f}}$ & $1.84 \pm 0.02^{\mathrm{f}}$ \\
\hline \multirow{2}{*}{21} & $\mathbf{C}$ & $196 \pm 1.06^{\mathbf{a}}$ & $194 \pm 0.73^{\mathrm{a}}$ & $40.40 \pm 0.64^{\mathbf{a}}$ & $73.98 \pm 1.62^{\mathrm{a}}$ & $1.54 \pm 0.01^{\mathrm{a}}$ & $2.95 \pm 0.01^{\mathrm{a}}$ \\
\hline & DEN & $339 \pm 1.78^{\mathrm{f}}$ & $344 \pm 1.16^{\mathbf{g}}$ & $16.95 \pm 0.68^{\mathbf{g}}$ & $45.32 \pm 1.25^{\mathrm{f}}$ & $0.66 \pm 0.01^{\mathrm{g}}$ & $1.76 \pm 0.01^{\mathrm{g}}$ \\
\hline \multirow{2}{*}{24} & $\mathbf{C}$ & $195 \pm 1.22^{\mathrm{a}}$ & $194 \pm 0.90^{\mathrm{a}}$ & $41.90 \pm 0.94^{\mathbf{a}}$ & $74.24 \pm 1.46^{\mathrm{a}}$ & $1.54 \pm 0.01^{\mathrm{a}}$ & $2.95 \pm 0.01^{\mathrm{a}}$ \\
\hline & DEN & $358 \pm 2.02^{\mathrm{g}}$ & $359 \pm 1.39^{\mathbf{h}}$ & $14.04 \pm 1.35^{\mathbf{h}}$ & $38.69 \pm 1.59^{\mathrm{g}}$ & $0.57 \pm 0.01^{\mathbf{h}}$ & $1.61 \pm 0.01^{\mathrm{h}}$ \\
\hline \multirow{2}{*}{27} & $\mathrm{C}$ & $194 \pm 1.07^{\mathrm{a}}$ & $194 \pm 0.77^{\mathrm{a}}$ & $41.97 \pm 0.81^{\mathbf{a}}$ & $73.72 \pm 1.49^{\mathrm{a}}$ & $1.54 \pm 0.01^{\mathrm{a}}$ & $2.95 \pm 0.01^{\mathrm{a}}$ \\
\hline & DEN & $378 \pm 2.06^{\mathbf{h}}$ & $382 \pm 0.82^{\mathrm{i}}$ & $11.09 \pm 0.79^{\mathbf{i}}$ & $28.91 \pm 1.64^{\mathbf{h}}$ & $0.50 \pm 0.01^{\mathrm{i}}$ & $1.51 \pm 0.01^{\mathrm{i}}$ \\
\hline
\end{tabular}

Results are expressed as mean \pm SE: standard error; Values not sharing common superscript are significant with each other at $\mathrm{p}<0.05$; W: weeks; $\mathrm{C}$ : control; DEN: diethylnitrosamine; TBARS: thiobarbituric acid reactive substances; AOPPs: advanced oxidation protein products; SOD: superoxide dismutase; CAT: catalase; GSH: reduced glutathione; NO: nitric oxide. 
Table (3): The serum liver function parameters of the DEN and control groups.

\begin{tabular}{|c|c|c|c|c|c|c|c|c|c|}
\hline $\mathbf{W}$ & Groups & $\begin{array}{l}\text { AST } \\
\text { (U/L) }\end{array}$ & $\begin{array}{l}\text { ALT } \\
\text { (U/L) }\end{array}$ & $\begin{array}{l}\text { ALP } \\
\text { (U/L) }\end{array}$ & $\begin{array}{r}\text { TBIL } \\
(\mathrm{mg} / \mathrm{dl})\end{array}$ & $\underset{(\mathrm{g} / \mathrm{dl})}{\mathrm{TP}}$ & $\begin{array}{l}\text { ALB } \\
(\mathrm{g} / \mathrm{dl})\end{array}$ & $\begin{array}{c}\text { GLOB } \\
(\mathrm{g} / \mathrm{dl})\end{array}$ & $\underset{(\mathrm{g} / \mathrm{dl})}{\mathbf{A} / \mathbf{G} \text { ratio }}$ \\
\hline \multirow{2}{*}{6} & C & $71.1 \pm 1.63^{\mathrm{a}}$ & $65.32 \pm 1.49^{\mathbf{a}}$ & $114 \pm 1.97^{\mathbf{a}}$ & $0.37 \pm 0.03^{\mathbf{a}}$ & $6.35 \pm 0.05^{\mathbf{a}}$ & $4.06 \pm 0.03^{\mathrm{a}}$ & $2.28 \pm 0.08^{\mathbf{a}}$ & $1.80 \pm 0.07^{\mathbf{a}}$ \\
\hline & DEN & $80.5 \pm 1.56^{\mathbf{b}}$ & $78.07 \pm 1.60^{\mathbf{b}}$ & $136 \pm 2.20^{\mathbf{b}}$ & $0.40 \pm 0.01^{\mathbf{a}}$ & $6.73 \pm 0.02^{\mathbf{b}}$ & $3.84 \pm 0.07^{\mathbf{b}}$ & $2.89 \pm 0.08^{\mathbf{b}}$ & $1.34 \pm 0.06^{\mathbf{b}}$ \\
\hline \multirow{2}{*}{9} & C & $70.9 \pm 1.56^{\mathrm{a}}$ & $64.62 \pm 1.50^{\mathrm{a}}$ & $114 \pm 1.83^{\mathrm{a}}$ & $0.35 \pm 0.03^{\mathbf{a}}$ & $6.26 \pm 0.06^{\mathbf{a}}$ & $4.07 \pm 0.04^{\mathbf{a}}$ & $2.19 \pm 0.08^{\mathbf{a}}$ & $1.88 \pm 0.08^{\mathrm{a}}$ \\
\hline & DEN & $105 \pm 2.08^{\mathbf{c}}$ & $85.25 \pm 2.31^{\mathbf{c}}$ & $155 \pm 1.97^{\mathbf{c}}$ & $0.80 \pm 0.03^{\mathbf{b}}$ & $6.91 \pm 0.01^{\mathbf{c}}$ & $3.62 \pm 0.04^{\mathbf{c}}$ & $3.29 \pm 0.04^{\mathbf{c}}$ & $1.10 \pm 0.02^{\mathbf{c}}$ \\
\hline \multirow{2}{*}{12} & C & $71.2 \pm 1.50^{\mathrm{a}}$ & $64.27 \pm 1.69^{\mathrm{a}}$ & $113 \pm 2.24^{\mathbf{a}}$ & $0.35 \pm 0.04^{\mathrm{a}}$ & $6.27 \pm 0.06^{\mathbf{a}}$ & $4.05 \pm 0.05^{\mathbf{a}}$ & $2.22 \pm 0.08^{\mathbf{a}}$ & $1.86 \pm 0.11^{\mathrm{a}}$ \\
\hline & DEN & $134 \pm 2.01^{\mathrm{d}}$ & $107.8 \pm 2.39^{\mathrm{d}}$ & $176 \pm 1.68^{d}$ & $1.03 \pm 0.03^{\mathbf{c}}$ & $7.16 \pm 0.03^{\mathrm{d}}$ & $3.42 \pm 0.01^{\mathrm{d}}$ & $3.73 \pm 0.03^{\mathrm{d}}$ & $0.91 \pm 0.01^{\mathbf{d}}$ \\
\hline \multirow{2}{*}{15} & C & $70.3 \pm 1.29^{\mathbf{a}}$ & $64.40 \pm 1.28^{\mathrm{a}}$ & $114 \pm 2.22^{\mathbf{a}}$ & $0.36 \pm 0.03^{\mathrm{a}}$ & $6.32 \pm 0.05^{\mathbf{a}}$ & $4.09 \pm 0.04^{\mathrm{a}}$ & $2.22 \pm 0.04^{\mathbf{a}}$ & $1.84 \pm 0.04^{\mathrm{a}}$ \\
\hline & DEN & $182 \pm 1.90^{\mathbf{e}}$ & $138.2 \pm 2.22^{\mathrm{e}}$ & $216 \pm 3.08^{\mathrm{e}}$ & $1.24 \pm 0.03^{\mathrm{d}}$ & $7.31 \pm 0.02^{\mathbf{e}}$ & $3.23 \pm 0.02^{\mathrm{e}}$ & $4.08 \pm 0.03^{\mathrm{e}}$ & $0.79 \pm 0.01^{\mathrm{de}}$ \\
\hline \multirow{2}{*}{18} & $\mathbf{C}$ & $70.1 \pm 1.40^{\mathbf{a}}$ & $65.18 \pm 1.39^{\mathrm{a}}$ & $115 \pm 1.66^{\mathbf{a}}$ & $0.37 \pm 0.04^{\mathbf{a}}$ & $6.29 \pm 0.07^{\mathbf{a}}$ & $4.01 \pm 0.03^{\mathbf{a}}$ & $2.28 \pm 0.07^{\mathrm{a}}$ & $1.77 \pm 0.07^{\mathbf{a}}$ \\
\hline & DEN & $241 \pm 2.26^{\mathrm{f}}$ & $158.4 \pm 2.34^{\mathbf{f}}$ & $257 \pm 2.98^{\text {f }}$ & $1.45 \pm 0.03^{\mathbf{e}}$ & $7.40 \pm 0.02^{\mathbf{e}}$ & $3.00 \pm 0.04^{\mathbf{f}}$ & $4.4 \pm 0.04^{\mathbf{f}}$ & $0.68 \pm 0.01^{\text {ef }}$ \\
\hline \multirow{2}{*}{21} & $\mathbf{C}$ & $70.7 \pm 1.48^{\mathbf{a}}$ & $64.61 \pm 1.37^{\mathbf{a}}$ & $114 \pm 1.42^{\mathbf{a}}$ & $0.35 \pm 0.03^{\mathbf{a}}$ & $6.26 \pm 0.07^{\mathrm{a}}$ & $4.06 \pm 0.04^{\mathrm{a}}$ & $2.20 \pm 0.08^{\mathbf{a}}$ & $1.87 \pm 0.08^{\mathbf{a}}$ \\
\hline & DEN & $298 \pm 2.38^{\mathbf{g}}$ & $185.9 \pm 2.23^{\mathrm{g}}$ & $304 \pm 2.43^{\mathrm{g}}$ & $1.73 \pm 0.02^{\mathbf{f}}$ & $7.60 \pm 0.01^{\mathbf{f}}$ & $2.78 \pm 0.01^{\mathrm{g}}$ & $4.82 \pm 0.02^{\mathrm{g}}$ & $0.57 \pm 0.00^{\mathrm{fg}}$ \\
\hline \multirow{2}{*}{24} & C & $70.7 \pm 1.42^{\mathbf{a}}$ & $64.43 \pm 1.40^{\mathrm{a}}$ & $114 \pm 1.73^{\mathrm{a}}$ & $0.36 \pm 0.03^{\mathbf{a}}$ & $6.35 \pm 0.04^{\mathbf{a}}$ & $4.04 \pm 0.04^{\mathrm{a}}$ & $2.30 \pm 0.07^{\mathrm{a}}$ & $1.77 \pm 0.08^{\mathrm{a}}$ \\
\hline & DEN & $353 \pm 2.22^{\mathrm{h}}$ & $200.4 \pm 2.09^{h}$ & $353 \pm 2.21^{\mathbf{h}}$ & $1.91 \pm 0.02^{\mathbf{g}}$ & $7.85 \pm 0.02^{\mathbf{g}}$ & $2.58 \pm 0.02^{\mathbf{h}}$ & $5.27 \pm 0.02^{\mathbf{h}}$ & $0.48 \pm 0.00^{\mathbf{g}}$ \\
\hline \multirow{2}{*}{27} & C & $71.8 \pm 1.69^{\mathrm{a}}$ & $64.71 \pm 1.36^{\mathrm{a}}$ & $115 \pm 1.51^{\mathrm{a}}$ & $0.35 \pm 0.04^{\mathrm{a}}$ & $6.27 \pm 0.06^{\mathrm{a}}$ & $4.04 \pm 0.04^{\mathrm{a}}$ & $2.23 \pm 0.08^{\mathbf{a}}$ & $1.84 \pm 0.09^{\mathrm{a}}$ \\
\hline & DEN & $375 \pm 2.31^{\mathbf{i}}$ & $218.5 \pm 2.45^{\mathbf{i}}$ & $379 \pm 2.93^{\mathbf{i}}$ & $2.21 \pm 0.06^{\mathbf{h}}$ & $7.9 \pm 0.02^{\mathbf{g}}$ & $2.33 \pm 0.02^{\mathbf{i}}$ & $5.56 \pm 0.03^{\mathrm{i}}$ & $0.42 \pm 0.00^{\mathrm{g}}$ \\
\hline
\end{tabular}

Results are expressed as mean \pm SE: standard error; Values not sharing common superscript are significant with each other at $\mathrm{p}<0.05$; W: weeks; C: control; DEN: diethylnitrosamine; AST: aspartate aminotransferase; ALT: alanine aminotransferase; ALP: alkaline phosphatase; TBIL: serum total bilirubin; TP: total protein; ALB: albumin; GLOB: globulin; A/G: albumin-globulin ratio. 
Table (4): Hepatocellular carcinoma tumor markers in the DEN and control groups.

\begin{tabular}{|c|c|c|c|c|c|c|c|}
\hline W & Groups & $\begin{array}{l}\text { GGT } \\
(\mathbf{U} / \mathbf{L})\end{array}$ & $\begin{array}{c}\text { AFU } \\
(\mathrm{pg} / \mathrm{ml})\end{array}$ & $\begin{array}{c}\text { AFP } \\
(n g / m l)\end{array}$ & $\begin{array}{c}\text { GPC3 } \\
(\mathrm{ng} / \mathrm{ml})\end{array}$ & $\begin{array}{c}\text { GP73 } \\
\text { (ng/ml) }\end{array}$ & $\begin{array}{l}\text { VEGF } \\
(n g / L)\end{array}$ \\
\hline \multirow{2}{*}{6} & $\mathbf{C}$ & $2.51 \pm 0.12^{\mathbf{a}}$ & $34.24 \pm 0.94^{\mathbf{a}}$ & $5.01 \pm 0.25^{\mathrm{a}}$ & $0 \pm 0^{\mathbf{a}}$ & $203 \pm 1.87^{\mathbf{a}}$ & $85.24 \pm 1.40^{\mathbf{a}}$ \\
\hline & DEN & $5.06 \pm 0.32^{\mathbf{b}}$ & $42.90 \pm 1.40^{\mathbf{b}}$ & $14.01 \pm 0.80^{\mathbf{b}}$ & $0 \pm 0^{\mathbf{a}}$ & $233 \pm 9.24^{\mathbf{b}}$ & $86.35 \pm 1.52^{\mathbf{a}}$ \\
\hline \multirow{2}{*}{9} & C & $2.53 \pm 0.12^{\mathbf{a}}$ & $34.81 \pm 1.02^{\mathbf{a}}$ & $4.96 \pm 0.28^{\mathbf{a}}$ & $0 \pm 0^{\mathbf{a}}$ & $203 \pm 1.76^{\mathbf{a}}$ & $85.96 \pm 1.74^{\mathbf{a}}$ \\
\hline & DEN & $7.92 \pm 0.33^{\mathbf{c}}$ & $53.28 \pm 2.34^{\mathbf{c}}$ & $24.67 \pm 1.06^{\mathbf{c}}$ & $0.21 \pm 0.01^{\mathbf{a}}$ & $270 \pm 2.60^{\mathbf{c}}$ & $86.57 \pm 0.42^{\mathbf{a}}$ \\
\hline \multirow{2}{*}{12} & C & $2.50 \pm 0.10^{\mathbf{a}}$ & $33.97 \pm 0.95^{\mathbf{a}}$ & $4.75 \pm 0.36^{\mathbf{a}}$ & $0 \pm 0^{\mathbf{a}}$ & $201 \pm 1.28^{\mathbf{a}}$ & $84.56 \pm 1.26^{\mathbf{a}}$ \\
\hline & DEN & $14.2 \pm 0.47^{\text {d }}$ & $76.54 \pm 1.89^{\text {d }}$ & $43.25 \pm 1.24^{\text {d }}$ & $0.50 \pm 0.02^{\mathbf{a}}$ & $300 \pm 2.30^{\mathbf{d}}$ & $95.41 \pm 1.22^{\mathbf{b}}$ \\
\hline \multirow{2}{*}{15} & C & $2.55 \pm 0.11^{\mathrm{a}}$ & $33.45 \pm 0.85^{\mathbf{a}}$ & $4.76 \pm 0.18^{\mathbf{a}}$ & $0 \pm 0^{\mathbf{a}}$ & $203 \pm 1.52^{\mathrm{a}}$ & $84.53 \pm 1.47^{\mathbf{a}}$ \\
\hline & DEN & $45.4 \pm 0.87^{\mathrm{e}}$ & $101.32 \pm 1.68^{\mathrm{e}}$ & $63.80 \pm 1.51{ }^{\mathrm{e}}$ & $8.46 \pm 0.53^{\mathrm{a}}$ & $351 \pm 10.6^{\mathbf{e}}$ & $107.17 \pm 1.15^{\mathbf{c}}$ \\
\hline \multirow{2}{*}{18} & C & $2.55 \pm 0.12^{\mathrm{a}}$ & $33.16 \pm 0.82^{\mathbf{a}}$ & $4.60 \pm 0.25^{\mathbf{a}}$ & $0 \pm 0^{\mathbf{a}}$ & $202 \pm 1.81^{\mathbf{a}}$ & $85.87 \pm 2.54^{\mathbf{a}}$ \\
\hline & DEN & $76.8 \pm 0.68$ f & $124.95 \pm 1.74^{\mathbf{f}}$ & $96.27 \pm 2.38^{\mathbf{f}}$ & $61.78 \pm 3.94^{\mathbf{b}}$ & $387 \pm 3.46^{\mathbf{f}}$ & $123.3 \pm 1.62^{d}$ \\
\hline \multirow{2}{*}{21} & C & $2.49 \pm 0.11^{\mathbf{a}}$ & $34.37 \pm 0.93^{\mathbf{a}}$ & $4.66 \pm 0.18^{\mathbf{a}}$ & $0 \pm 0^{\mathbf{a}}$ & $202 \pm 1.27^{\mathbf{a}}$ & $84.43 \pm 1.33^{\mathbf{a}}$ \\
\hline & DEN & $109 . \pm 0.99^{\mathbf{g}}$ & $173.30 \pm 1.78^{\mathbf{g}}$ & $153.78 \pm 2.26^{\mathbf{g}}$ & $243.05 \pm 11.3^{\mathbf{c}}$ & $450 \pm 2.68^{\mathbf{g}}$ & $143.02 \pm 1.52^{\mathrm{e}}$ \\
\hline \multirow{2}{*}{24} & C & $2.49 \pm 0.12^{\mathbf{a}}$ & $34.34 \pm 0.89^{\mathbf{a}}$ & $4.70 \pm 0.22^{\mathbf{a}}$ & $0 \pm 0^{\mathbf{a}}$ & $202 \pm 1.65^{\mathbf{a}}$ & $85.38 \pm 1.40^{\mathbf{a}}$ \\
\hline & DEN & $130 . \pm 0.80^{\mathbf{h}}$ & $205.61 \pm 2.10^{\mathbf{h}}$ & $181.86 \pm 2.22^{\mathbf{h}}$ & $473.54 \pm 3.59^{d}$ & $489 \pm 2.37^{\mathbf{h}}$ & $155.35 \pm 1.72^{\mathbf{f}}$ \\
\hline \multirow{2}{*}{27} & C & $2.54 \pm 0.10^{\mathbf{a}}$ & $34.49 \pm 0.92^{\mathbf{a}}$ & $4.63 \pm 0.14^{\mathbf{a}}$ & $0 \pm 0^{\mathbf{a}}$ & $202 \pm 1.38^{\mathbf{a}}$ & $84.12 \pm 1.62^{\mathrm{a}}$ \\
\hline & DEN & $149 . \pm 0.86^{\mathbf{i}}$ & $242.28 \pm 1.68^{\mathbf{i}}$ & $199.54 \pm 2.56^{\mathbf{i}}$ & $867.35 \pm 4.38^{\mathbf{e}}$ & $527 \pm 2.05^{\mathbf{i}}$ & $176.87 \pm 2.44^{\mathbf{g}}$ \\
\hline
\end{tabular}

Results are expressed as mean $\pm \mathrm{SE}$ : standard error; Values not sharing common superscript are significant with each other at $\mathrm{p}<0.001$; W: weeks; C: control; DEN: diethylnitrosamine; GGT: $\gamma$ glutamyl transferase; AFU: alpha-1-fucosidase; AFP: alpha-fetoprotein; GPC3: glypican-3; GP73: Golgi protein 73; VEGF: vascular endothelial growth factor. 
Table (5): The serum lipid profile and lipid risk ratios in the DEN and control groups.

\begin{tabular}{|c|c|c|c|c|c|c|c|c|}
\hline $\mathbf{W}$ & Groups & $\underset{(\mathbf{m g} / \mathbf{d l})}{\mathrm{TG}}$ & TC (mg/dl) & $\begin{array}{r}\text { HDL-C } \\
(\mathrm{mg} / \mathrm{dl})\end{array}$ & $\begin{array}{l}\text { LDL-C } \\
(\mathbf{m g} / \mathrm{dl})\end{array}$ & $\begin{array}{c}\text { TG/HDL-C } \\
\text { risk ratio } \\
\text { (mg/dl) }\end{array}$ & $\begin{array}{c}\text { TC/HDL-C } \\
\text { risk ratio } \\
\text { (mg/dl) }\end{array}$ & $\begin{array}{c}\text { LDL- } \\
\text { C/HDL-C } \\
\text { risk ratio } \\
\text { (mg/dl) }\end{array}$ \\
\hline \multirow{2}{*}{6} & C & $81.53 \pm 1.44^{\mathbf{a}}$ & $98.21 \pm 1.23^{\mathbf{a}}$ & $65.91 \pm 1.59^{\mathbf{a}}$ & $15.99 \pm 1.70^{\mathbf{a}}$ & $1.24 \pm 0.04^{\mathrm{a}}$ & $1.49 \pm 0.03^{\mathrm{a}}$ & $0.24 \pm 0.03^{\mathbf{a}}$ \\
\hline & DEN & $91.44 \pm 1.72^{\mathbf{b}}$ & $111.59 \pm 1.19^{\mathbf{b}}$ & $60.77 \pm 1.56^{\mathbf{b}}$ & $32.52 \pm 2.25^{\mathbf{b}}$ & $1.51 \pm 0.05^{\mathbf{a b}}$ & $1.84 \pm 0.05^{\mathbf{a b}}$ & $0.54 \pm 0.04^{\mathbf{a b}}$ \\
\hline \multirow{2}{*}{9} & $\mathrm{C}$ & $80.91 \pm 1.54^{\mathbf{a}}$ & $97.20 \pm 1.46^{\mathrm{a}}$ & $64.89 \pm 1.65^{\mathbf{a b}}$ & $16.13 \pm 1.99^{\mathrm{a}}$ & $1.25 \pm 0.04^{\mathbf{a}}$ & $1.50 \pm 0.03^{\mathrm{a}}$ & $0.25 \pm 0.03^{\mathbf{a}}$ \\
\hline & DEN & $102.02 \pm 1.64^{\mathbf{C}}$ & $124.82 \pm 1.36^{\mathbf{c}}$ & $53.21 \pm 1.58^{\mathbf{c}}$ & $51.19 \pm 2.05^{\mathbf{c}}$ & $1.93 \pm 0.08^{\mathbf{b}}$ & $2.36 \pm 0.08^{\mathbf{b}}$ & $0.97 \pm 0.06^{\mathbf{b}}$ \\
\hline \multirow{2}{*}{12} & $\mathbf{C}$ & $81.69 \pm 1.52^{\mathrm{a}}$ & $98.46 \pm 1.58^{\mathrm{a}}$ & $64.37 \pm 1.52^{\mathbf{a b}}$ & $17.75 \pm 2.51^{\mathbf{a}}$ & $1.27 \pm 0.03^{\mathbf{a}}$ & $1.53 \pm 0.04^{\mathrm{a}}$ & $0.28 \pm 0.04^{\mathbf{a}}$ \\
\hline & DEN & $113.99 \pm 1.44^{\mathbf{d}}$ & $137.06 \pm 1.14^{\mathbf{d}}$ & $45.91 \pm 1.52^{\text {d }}$ & $68.34 \pm 2.30^{\text {d }}$ & $2.50 \pm 0.07^{\mathbf{c}}$ & $3.01 \pm 0.11 \mathrm{c}$ & $1.51 \pm 0.10^{\mathbf{c}}$ \\
\hline \multirow{2}{*}{15} & C & $81.14 \pm 1.50^{\mathrm{a}}$ & $97.83 \pm 1.43^{\mathbf{a}}$ & $64.03 \pm 1.50^{\mathbf{a b}}$ & $17.56 \pm 2.36^{\mathrm{a}}$ & $1.27 \pm 0.03^{\mathrm{a}}$ & $1.53 \pm 0.05^{\mathrm{a}}$ & $0.28 \pm 0.04^{\mathbf{a}}$ \\
\hline & DEN & $125.98 \pm 1.46^{\mathbf{e}}$ & $150.61 \pm 1.54^{\mathrm{e}}$ & $39.56 \pm 1.54^{\mathrm{e}}$ & $85.85 \pm 2.11{ }^{\mathbf{e}}$ & $3.22 \pm 0.12^{\mathbf{d}}$ & $3.85 \pm 0.15^{\mathbf{d}}$ & $2.21 \pm 0.13^{\mathbf{d}}$ \\
\hline \multirow{2}{*}{18} & C & $80.05 \pm 1.50^{\mathrm{a}}$ & $97.59 \pm 1.52^{\mathrm{a}}$ & $64.07 \pm 1.63^{\mathbf{a b}}$ & $17.50 \pm 2.04^{\mathrm{a}}$ & $1.25 \pm 0.04^{\mathrm{a}}$ & $1.53 \pm 0.04^{\mathrm{a}}$ & $0.27 \pm 0.03^{\mathrm{a}}$ \\
\hline & DEN & $131.08 \pm 1.65^{\mathbf{f}}$ & $165.29 \pm 1.85^{\mathbf{f}}$ & $33.08 \pm 1.53^{\mathbf{f}}$ & $105.98 \pm 2.81^{\mathbf{f}}$ & $4.02 \pm 0.16^{\mathbf{e}}$ & $5.10 \pm 0.26^{\mathbf{e}}$ & $3.29 \pm 0.22{ }^{\mathbf{e}}$ \\
\hline \multirow{2}{*}{21} & C & $80.43 \pm 1.48^{\mathbf{a}}$ & $97.09 \pm 1.78^{\mathrm{a}}$ & $65.16 \pm 1.66^{\mathbf{a}}$ & $15.83 \pm 2.57^{\mathbf{a}}$ & $1.23 \pm 0.02^{\mathbf{a}}$ & $1.49 \pm 0.04^{\mathbf{a}}$ & $0.25 \pm 0.04^{\mathbf{a}}$ \\
\hline & DEN & $142.85 \pm 1.52^{\mathbf{g}}$ & $184.10 \pm 2.21^{\mathbf{g}}$ & $29.86 \pm 1.56^{\mathbf{f}}$ & $125.66 \pm 3.11^{\mathbf{g}}$ & $4.89 \pm 0.24^{\mathbf{f}}$ & $6.33 \pm 0.37^{\mathbf{f}}$ & $4.35 \pm 0.32 \mathbf{f}$ \\
\hline \multirow{2}{*}{24} & C & $80.52 \pm 1.54^{\mathrm{a}}$ & $98.36 \pm 1.08^{\mathbf{a}}$ & $65.09 \pm 1.57^{\mathrm{a}}$ & $17.16 \pm 2.22^{\mathbf{a}}$ & $1.24 \pm 0.04^{\mathrm{a}}$ & $1.52 \pm 0.04^{\mathrm{a}}$ & $0.27 \pm 0.03^{\mathbf{a}}$ \\
\hline & DEN & $161.60 \pm 1.71^{\mathbf{h}}$ & $198.51 \pm 1.57^{\mathbf{h}}$ & $23.94 \pm 1.60^{\mathbf{g}}$ & $142.25 \pm 2.68^{\text {h }}$ & $7.00 \pm 0.43^{\mathbf{g}}$ & $8.63 \pm 0.56^{\mathbf{g}}$ & $6.22 \pm 0.48^{\mathbf{g}}$ \\
\hline \multirow{2}{*}{27} & C & $80.97 \pm 1.52^{\mathbf{a}}$ & $97.01 \pm 1.78^{\mathrm{a}}$ & $64.26 \pm 1.55^{\mathbf{a b}}$ & $16.55 \pm 2.28^{\mathrm{a}}$ & $1.26 \pm 0.03^{\mathbf{a}}$ & $1.51 \pm 0.04^{\mathbf{a}}$ & $0.26 \pm 0.03^{\mathrm{a}}$ \\
\hline & DEN & $179.81 \pm 1.93^{\mathbf{i}}$ & $212.76 \pm 1.81^{\mathbf{i}}$ & $18.02 \pm 0.54^{\mathbf{h}}$ & $158.76 \pm 2.05^{\mathbf{i}}$ & $10.0 \pm 0.26^{\mathbf{h}}$ & $11.9 \pm 0.40^{\mathbf{h}}$ & $8.89 \pm 0.36^{\mathbf{h}}$ \\
\hline
\end{tabular}

Results are expressed as mean \pm SE: standard error; Values not sharing common superscript are significant with each other at $\mathrm{p}<0.05$; W: weeks; C: control; DEN: diethylnitrosamine; TG: triglycerides; TC: total cholesterol: HDL-C: high-density lipoprotein cholesterol; LDL-C: low-density lipoprotein cholesterol. 
Table (6): The hematological values in the DEN and control groups.

\begin{tabular}{|c|c|c|c|c|c|c|c|c|c|}
\hline \multirow{2}{*}{ W } & \multirow{2}{*}{ Groups } & \multirow{2}{*}{$\begin{array}{c}\text { RBC count } \\
\left(\times 10^{6} / \mathrm{mm}^{3}\right)\end{array}$} & \multirow{2}{*}{$\begin{array}{c}\mathrm{Hb} \\
\text { concentration } \\
(\mathrm{g} / \mathrm{dl})\end{array}$} & \multirow{2}{*}{ HCT (\%) } & \multirow{2}{*}{$\begin{array}{c}\text { Platelet } \\
\text { count } \\
\left(10^{3} / \mathbf{m m}^{3}\right)\end{array}$} & \multirow{2}{*}{$\begin{array}{c}\text { WBC } \\
\text { count } \\
\left(10^{3} / \mathrm{mm}^{3}\right)\end{array}$} & \multicolumn{3}{|c|}{ Differential leukocytic count } \\
\hline & & & & & & & $\begin{array}{c}\text { Lymphocytes } \\
(\%)\end{array}$ & $\begin{array}{c}\text { Neutrophils } \\
(\%)\end{array}$ & $\begin{array}{c}\text { Monocytes } \\
(\%)\end{array}$ \\
\hline \multirow[b]{2}{*}{6} & C & & $15.74 \pm 0.07^{\mathbf{a}}$ & $47.2 \pm 0.12^{\mathbf{a}}$ & $938 \pm 2.80^{\mathbf{a}}$ & $9.69 \pm 0.05^{\mathrm{a}}$ & $72.6 \pm 0.33^{\mathbf{a}}$ & $19.6 \pm 0.16^{\mathrm{a}}$ & $4.1 \pm 0.23^{\mathbf{a}}$ \\
\hline & DEN & $7.86 \pm 0.03^{\mathbf{b}}$ & $14.33 \pm 0.06^{\mathbf{b}}$ & $43.10 \pm 0.21^{\mathbf{b}}$ & $889 \pm 2.04^{\mathbf{b}}$ & $8.91 \pm 0.03^{\mathbf{b}}$ & $72.8 \pm 0.24^{\mathbf{a}}$ & $19.9 \pm 0.23^{\mathbf{a}}$ & $4.2 \pm 0.2^{\mathbf{a}}$ \\
\hline \multirow{2}{*}{9} & C & $8.58 \pm 0.07^{\mathrm{a}}$ & $15.67 \pm 0.10^{\mathrm{a}}$ & $47.22 \pm 0.24^{\mathbf{a}}$ & $935 \pm 2.76^{\mathbf{a}}$ & $9.69 \pm 0.04^{\mathrm{a}}$ & $72.4 \pm 0.22^{\mathbf{a}}$ & $19.5 \pm 0.16^{\mathbf{a}}$ & $4 \pm 0.25^{\mathbf{a}}$ \\
\hline & DEN & $7.47 \pm 0.04^{\mathbf{c}}$ & $13.59 \pm 0.08^{\mathbf{c}}$ & $40.81 \pm 0.20^{\mathbf{c}}$ & $842 \pm 2.23^{\mathbf{c}}$ & $8.42 \pm 0.03^{\mathbf{c}}$ & $70.6 \pm 0.16^{\mathbf{b}}$ & $20.5 \pm 0.22^{\mathbf{b}}$ & $4.3 \pm 0.15^{\mathbf{a}}$ \\
\hline \multirow{2}{*}{12} & $\mathbf{C}$ & $8.55 \pm 0.08^{\mathbf{a}}$ & $15.55 \pm 0.14^{\mathbf{a}}$ & $47.53 \pm 0.23^{\mathbf{a}}$ & $933 \pm 3.49^{\mathbf{a}}$ & $9.68 \pm 0.04^{\mathrm{a}}$ & $72.6 \pm 0.37^{\mathbf{a}}$ & $19.5 \pm 0.16^{\mathbf{a}}$ & $4.1 \pm 0.17^{\mathbf{a}}$ \\
\hline & DEN & $7.12 \pm 0.03^{\mathbf{d}}$ & $12.94 \pm 0.07^{\mathbf{d}}$ & $39.01 \pm 0.15^{\mathbf{d}}$ & $730 \pm 2.23^{\mathbf{d}}$ & $7.70 \pm 0.02^{\mathrm{d}}$ & $68.3 \pm 0.21{ }^{\mathbf{c}}$ & $21.5 \pm 0.16^{\mathbf{c}}$ & $5.2 \pm 0.35^{\mathbf{b}}$ \\
\hline \multirow{2}{*}{15} & C & $8.64 \pm 0.04^{\mathbf{a}}$ & $15.72 \pm 0.08^{\mathbf{a}}$ & $47.13 \pm 0.20^{\mathbf{a}}$ & $935 \pm 2.88^{\mathbf{a}}$ & $9.74 \pm 0.04^{\mathbf{a}}$ & $72.6 \pm 0.33^{\mathbf{a}}$ & $19.4 \pm 0.16^{\mathbf{a}}$ & $4.2 \pm 0.24^{\mathbf{a}}$ \\
\hline & DEN & $6.53 \pm 0.05^{\mathbf{e}}$ & $11.88 \pm 0.10^{\mathbf{e}}$ & $35.60 \pm 0.31{ }^{\mathbf{e}}$ & $642 \pm 2.57^{\mathbf{e}}$ & $6.85 \pm 0.02^{\mathbf{e}}$ & $66.8 \pm 0.24^{d}$ & $22.6 \pm 0.16^{d}$ & $5.6 \pm 0.22^{\mathbf{b c}}$ \\
\hline \multirow{2}{*}{18} & C & $8.66 \pm 0.06^{\mathbf{a}}$ & $15.73 \pm 0.10^{\mathbf{a}}$ & $47.07 \pm 0.28^{\mathbf{a}}$ & $934 \pm 2.77^{\mathbf{a}}$ & $9.75 \pm 0.03^{\mathbf{a}}$ & $72.4 \pm 0.33^{\mathbf{a}}$ & $19.6 \pm 0.16^{\mathbf{a}}$ & $4.1 \pm 0.17^{\mathbf{a}}$ \\
\hline & DEN & $5.99 \pm 0.08^{\mathbf{f}}$ & $10.92 \pm 0.14^{\mathbf{f}}$ & $32.48 \pm 0.30^{\mathbf{f}}$ & $550 \pm 3.67^{\mathbf{f}}$ & $6.13 \pm 0.03^{\mathbf{f}}$ & $65.9 \pm 0.23^{\mathbf{e}}$ & $23.5 \pm 0.16^{\mathbf{e}}$ & $5.6 \pm 0.30^{\text {bd }}$ \\
\hline \multirow{2}{*}{21} & $\mathbf{C}$ & $8.50 \pm 0.07^{\mathbf{a}}$ & $15.47 \pm 0.12^{\mathbf{a}}$ & $47.11 \pm 0.16^{\mathbf{a}}$ & $933 \pm 3.17^{\mathbf{a}}$ & $9.70 \pm 0.03^{\mathbf{a}}$ & $72.5 \pm 0.26^{\mathbf{a}}$ & $19.4 \pm 0.16^{\mathbf{a}}$ & $4.2 \pm 0.2^{\mathbf{a}}$ \\
\hline & DEN & $5.37 \pm 0.05^{\mathbf{g}}$ & $9.77 \pm 0.09^{\mathbf{g}}$ & $29.37 \pm 0.30^{\mathbf{g}}$ & $463 \pm 2.48^{\mathbf{g}}$ & $5.27 \pm 0.02^{\mathbf{g}}$ & $64.8 \pm 0.24^{\mathbf{f}}$ & $24.3 \pm 0.21^{\mathbf{f}}$ & $5.9 \pm 0.23^{\mathbf{c d}}$ \\
\hline \multirow{2}{*}{24} & C & $8.52 \pm 0.05^{\mathbf{a}}$ & $15.49 \pm 0.10^{\mathbf{a}}$ & $46.93 \pm 0.12^{\mathbf{a}}$ & $934 \pm 3.42^{\mathbf{a}}$ & $9.75 \pm 0.04^{\mathbf{a}}$ & $72.2 \pm 0.35^{\mathbf{a}}$ & $19.5 \pm 0.16^{\mathbf{a}}$ & $4 \pm 0.25^{\mathbf{a}}$ \\
\hline & DEN & $5.16 \pm 0.06^{\mathbf{h}}$ & $9.40 \pm 0.10^{\mathbf{h}}$ & $28.19 \pm 0.22^{\mathbf{h}}$ & $377 \pm 2.40^{\mathbf{h}}$ & $4.82 \pm 0.02^{\mathbf{h}}$ & $63.5 \pm 0.16^{\mathbf{g}}$ & $24.9 \pm 0.23^{\mathbf{g}}$ & $6.6 \pm 0.26^{\mathbf{e}}$ \\
\hline \multirow{2}{*}{27} & C & $8.60 \pm 0.05^{\mathbf{a}}$ & $15.63 \pm 0.09^{\mathbf{a}}$ & $47.02 \pm 0.12^{\mathbf{a}}$ & $937 \pm 2.70^{\mathbf{a}}$ & $9.76 \pm 0.04^{\mathbf{a}}$ & $72.5 \pm 0.34^{\mathbf{a}}$ & $19.5 \pm 0.16^{\mathbf{a}}$ & $4 \pm 0.25^{\mathbf{a}}$ \\
\hline & DEN & $4.72 \pm 0.04^{\mathbf{i}}$ & $8.57 \pm 0.06^{\mathbf{i}}$ & $25.56 \pm 0.25^{\mathbf{i}}$ & $289 \pm 2.25^{\mathbf{i}}$ & $4.50 \pm 0.06^{\mathbf{i}}$ & $62.9 \pm 0.23^{\mathbf{g}}$ & $24.9 \pm 0.23^{\mathbf{g}}$ & $7.2 \pm 0.32^{\mathbf{e}}$ \\
\hline
\end{tabular}

Results are expressed as mean $\pm \mathrm{SE}$ : standard error; Values not sharing common superscript are significant with each other at $\mathrm{p}<0.05$; W: weeks; $\mathrm{C}$ : control; DEN: diethylnitrosamine; RBC: red blood corpuscle; Hb: hemoglobin; Hct: hematocrit; WBC: white blood cell. 
Table (7): Bashandy, Mansour \& Fathy (BMF) staging system for prognosis and treatment allocation of hepatocellular carcinoma (HCC) in diethylnitrosamine induced male Wistar albino rat model.

\begin{tabular}{|c|c|c|c|c|c|}
\hline \multirow[b]{2}{*}{ Parameters } & \multicolumn{4}{|c|}{ HCC stages } & \multirow[b]{2}{*}{$\begin{array}{c}\text { Reference } \\
\text { (6-27 weeks) }\end{array}$} \\
\hline & $\begin{array}{c}\text { Early stage } \\
(6-12 \text { weeks })\end{array}$ & $\begin{array}{c}\text { Intermediate stage } \\
(15-18 \text { weeks })\end{array}$ & $\begin{array}{c}\text { Advanced stage } \\
\text { (18-21 weeks) }\end{array}$ & $\begin{array}{c}\text { Late stage } \\
(24-27 \text { weeks })\end{array}$ & \\
\hline The body weight gain (\%) & $31.32 \%-47.60 \%$ & $50.16 \%-33.99 \%$ & $33.99 \%-31.38 \%$ & $34.57 \%-31.00 \%$ & $37.16 \%-71.31 \%$ \\
\hline The relative liver weight (g) & 2.39-3.99 & $4.57-8.57$ & $8.57-11.73$ & 12.07-12.91 & $2.49-2.80$ \\
\hline Nodule incidence (\%) & $0 \%-70 \%$ & $80 \%-100 \%$ & $100 \%$ & $100 \%$ & $0 \%$ \\
\hline Nodules $<1 \mathrm{~mm}$ in diameter & $0 \%-100 \%$ & $66.28 \%-62.40 \%$ & $62.40 \%-50.27 \%$ & $45.88 \%-42.43 \%$ & $0 \%$ \\
\hline Nodules 1-3 $\mathrm{mm}$ in diameter & $0 \%-21.21 \%$ & $28.49 \%-31.85 \%$ & $31.85 \%-33.73 \%$ & $34.55 \%-35.61 \%$ & $0 \%$ \\
\hline Nodules $>\mathbf{3} \mathbf{m m}$ in diameter & $0 \%$ & $5.23 \%-5.74 \%$ & $5.74 \%-16.00 \%$ & $19.57 \%-21.96 \%$ & $0 \%$ \\
\hline The average no. of nodules & $0-7.33$ & $17.2-38.3$ & $38.3-75$ & 93.5-114 & 0 \\
\hline The mortality rate $(\%)$ & $0 \%-6.67 \%$ & $13.33 \%-20.00 \%$ & $20.00 \%-33.33 \%$ & $46.67 \%-60.00 \%$ & $0 \%$ \\
\hline GGT (U/L) & $5.06-14.2$ & $45.4-76.8$ & $76.8-109.0$ & $130.0-149.0$ & $2.49-2.54$ \\
\hline $\mathbf{A F U}(\mathrm{pg} / \mathrm{ml})$ & $42.90-76.54$ & $101.3-124.9$ & $124.9-173.3$ & $205.6-242.3$ & $33.16-34.81$ \\
\hline $\operatorname{AFP}(\mathrm{ng} / \mathrm{ml})$ & $14.01-43.25$ & $63.80-96.27$ & $96.27-153.8$ & 181.9-199.5 & $4.60-5.01$ \\
\hline AFP-L3 (ng/ml) & $0.57-12.80$ & $21.37-33.69$ & $33.69-70.44$ & $91.49-119.5$ & $0.05-0.07$ \\
\hline GPC3 (ng/ml) & $0-0.50$ & $8.46-61.78$ & $61.78-243.0$ & $473.5-867.3$ & 0 \\
\hline GP73 (ng/ml) & $233-300$ & $351-387$ & $387-450$ & 489-527 & $201-203$ \\
\hline VEGF (ng/L) & $86.35-95.41$ & $107.2-123.3$ & $123.3-143.0$ & $155.3-176.9$ & $84.12-85.96$ \\
\hline TBARS (nmole/gtissue) & $197-251$ & $270-315$ & $315-339$ & $358-378$ & 193-196 \\
\hline AOPPs (nmole/gtissue) & $200-254$ & $275-314$ & $314-344$ & $359-382$ & 194-195 \\
\hline NO $(\mu \mathrm{mol} / \mathrm{g}$ tissue $)$ & $37.21-32.36$ & $25.99-20.48$ & $20.48-16.95$ & 14.04-11.09 & $40.96-41.91$ \\
\hline SOD (U/mg tissue) & $69.26-59.86$ & $54.88-51.27$ & $51.27-45.32$ & $38.69-28.91$ & $73.72-74.59$ \\
\hline CAT (U/mg tissue) & $1.32-0.97$ & $0.87-0.76$ & $0.76-0.66$ & $0.57-0.50$ & $1.54-1.55$ \\
\hline GSH (nmol/g tissue) & $2.33-2.03$ & $1.94-1.84$ & $1.84-1.76$ & $1.61-1.51$ & $2.94-2.96$ \\
\hline $\operatorname{AST}(\mathbf{U} / \mathbf{L})$ & $80.5-134$ & $182-241$ & $241-298$ & $353-375$ & $70.1-71.8$ \\
\hline $\operatorname{ALT}(\mathbf{U} / \mathbf{L})$ & $78.07-107.8$ & $138.2-158.4$ & 158.4-185.9 & $200.4-218.5$ & $64.27-65.32$ \\
\hline $\mathbf{A L P}(\mathbf{U} / \mathbf{L})$ & 136-176 & $216-257$ & $257-304$ & $353-379$ & 113-115 \\
\hline TBIL (mg/dl) & $0.40-1.03$ & $1.24-1.45$ & $1.45-1.73$ & $1.91-2.21$ & $0.35-0.37$ \\
\hline Total protein (g/dl) & $6.73-7.16$ & $7.31-7.40$ & $7.40-7.60$ & $7.85-7.9$ & $6.26-6.35$ \\
\hline Albumin (g/dl) & $3.84-3.42$ & $3.23-3.00$ & $3.00-2.78$ & $2.58-2.33$ & $4.01-4.09$ \\
\hline Globulin (g/dl) & $2.89-3.73$ & $4.08-4.4$ & $4.4-4.82$ & $5.27-5.56$ & $2.19-2.30$ \\
\hline A/G ratio (g/dl) & $1.34-0.91$ & $0.79-0.68$ & $0.68-0.57$ & $0.48-0.42$ & $1.77-1.88$ \\
\hline TG (mg/dl) & $91.44-113.99$ & $125.98-131.08$ & $131.08-142.85$ & $161.60-179.81$ & $80.05-81.69$ \\
\hline TC (mg/dl) & $111.59-137.06$ & $150.61-165.29$ & $165.29-184.10$ & $198.51-212.76$ & $97.01-98.46$ \\
\hline HDL-C (mg/dl) & $60.77-45.91$ & $39.56-33.08$ & $33.08-29.86$ & 23.94-18.02 & $64.03-65.91$ \\
\hline LDL-C (mg/dl) & $32.52-68.34$ & $85.85-105.98$ & $105.98-125.66$ & $142.25-158.76$ & $15.83-17.75$ \\
\hline $\begin{array}{l}\text { TG/HDL-C, TC/HDL-C \& } \\
\text { LDL-C/HDL-C risk ratios }\end{array}$ & Risk & Risk & Risk & Risk & Not risk \\
\hline $\mathrm{RBC}$ count $\left(\mathrm{X} 10^{6} / \mathrm{mm}^{3}\right)$ & $7.86-7.12$ & $6.53-5.99$ & $5.99-5.37$ & $5.16-4.72$ & $8.50-8.66$ \\
\hline Hb concentration $(\mathrm{g} / \mathrm{dl})$ & 14.33-12.94 & $11.88-10.92$ & $10.92-9.77$ & $9.40-8.57$ & $15.47-15.73$ \\
\hline Hct percentage & $43.10 \%-39.01 \%$ & $35.60 \%-32.48 \%$ & $32.48 \%-29.37 \%$ & $28.19 \%-25.56 \%$ & $46.93 \%-47.22 \%$ \\
\hline Platelet count $\left(10^{3} / \mathrm{mm}^{3}\right)$ & $889-730$ & $642-550$ & $550-463$ & $377-289$ & 933-938 \\
\hline WBC count $\left(10^{3} / \mathrm{mm}^{3}\right)$ & $8.91-7.70$ & $6.85-6.13$ & $6.13-5.27$ & $4.82-4.50$ & $9.68-9.76$ \\
\hline $\begin{array}{c}\text { combined } \\
\text { modality } \\
\text { treatment }\end{array}$ & $\begin{array}{c}\text { Chemoprevention } \\
\text { or phytotherapeutic } \\
\text { agent } \\
\text { or hepatic resection, } \\
\text { reversible, } \\
\text { curative stage }\end{array}$ & $\begin{array}{c}\text { Phytotherapeutic } \\
\text { agent \& } \\
\text { radiofrequency } \\
\text { ablation or trans- } \\
\text { arterial therapies } \\
\text { (chemoembolization) }\end{array}$ & $\begin{array}{c}\text { Phytotherapeutic } \\
\text { Agent } \\
\text { \& radiofrequency } \\
\text { ablation } \\
\text { and/or trans-arterial } \\
\text { or targeted therapies }\end{array}$ & $\begin{array}{l}\text { Symptomatic } \\
\text { treatment, } \\
\text { irreversible, } \\
\text { uncurative } \\
\text { stage }\end{array}$ & \\
\hline $\begin{array}{l}\text { GGT: } \gamma \text {-glutamyl transf } \\
\text { VEGF: vascular endothe } \\
\text { products; SOD: supero } \\
\text { aminotransferase; ALT: } \\
\text { globulin ratio; TG: trig }\end{array}$ & $\begin{array}{l}\text { ase; AFU: alpha-1-fuc } \\
\text { l growth factor; TBA } \\
\text { ide dismutase; CAT } \\
\text { lanine aminotransfer } \\
\text { cerides; TC: total cl }\end{array}$ & $\begin{array}{l}\text { sidase; AFP: alpha-fe } \\
\text { S: thiobarbituric acid } \\
\text { catalase; GSH: red } \\
\text { e; ALP: alkaline pho } \\
\text { lesterol: HDL-C: hig }\end{array}$ & oprotein; GPC3: glyp & $\begin{array}{l}\text { n-3; GP73: Golgi } \\
\text { Ps: advanced oxid; } \\
\text { nitric oxide; AS } \\
\text { otal bilirubin; A/ } \\
\text { lesterol; LDL-C: } \\
\text { blood cell. }\end{array}$ & $\begin{array}{l}\text { protein } 73 ; \\
\text { tion protein } \\
: \text { aspartate } \\
\text { : albumin- } \\
\text { low-density }\end{array}$ \\
\hline
\end{tabular}




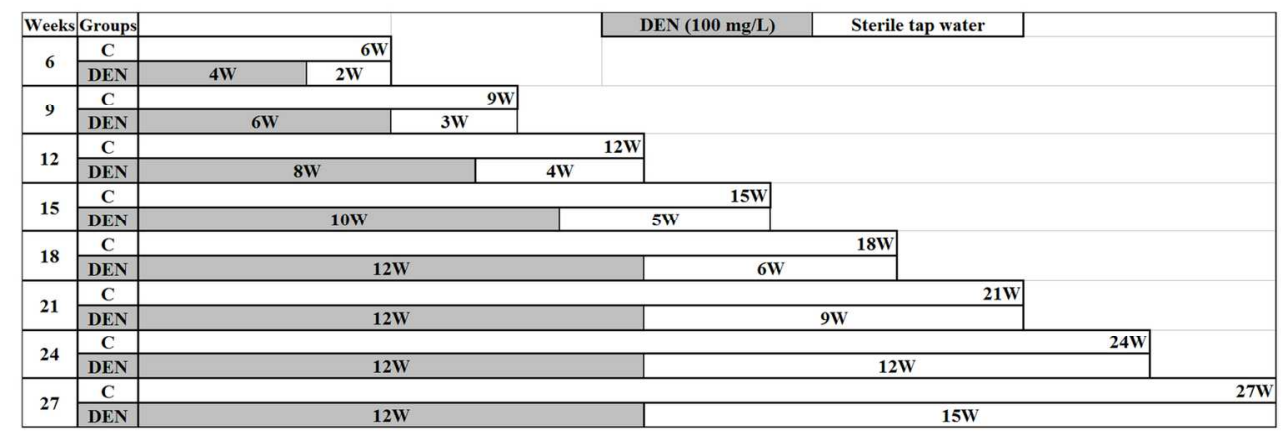

The experimental schedules of diethylnitrosamine (DEN) administered and control (C) groups during 27 weeks.

$76 \times 26 \mathrm{~mm}(600 \times 600 \mathrm{DPI})$ 


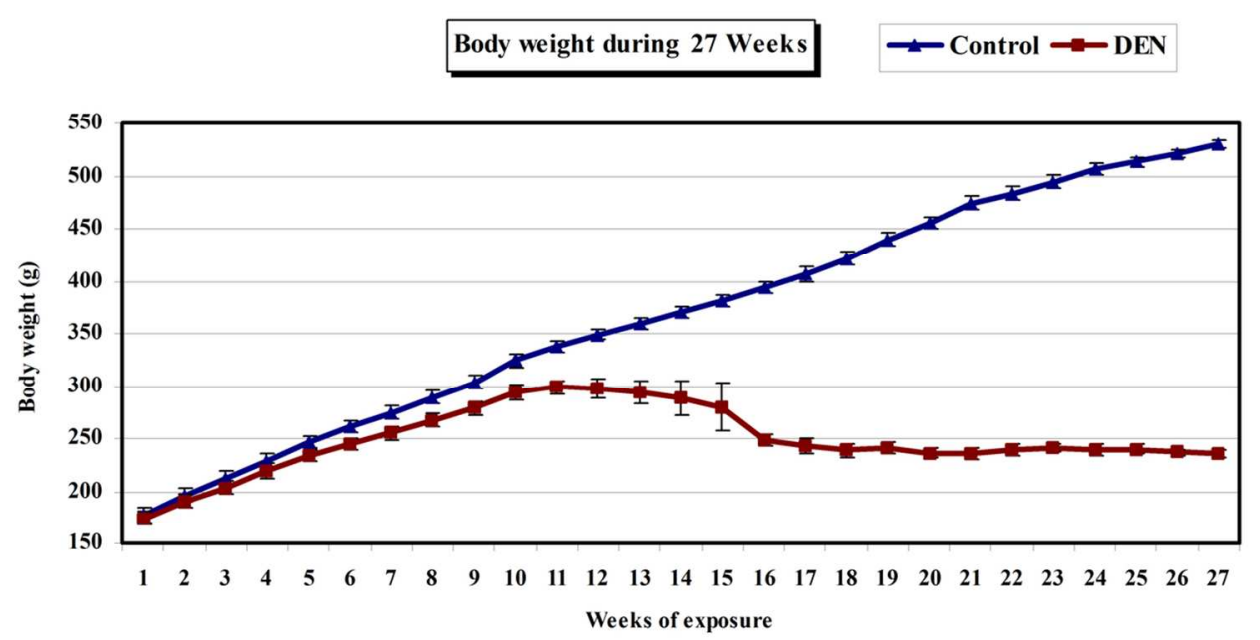

The chronological changes of body weight during 27 weeks in the control and diethylnitrosamine (DEN) administered groups.

$111 \times 57 \mathrm{~mm}(300 \times 300$ DPI) 


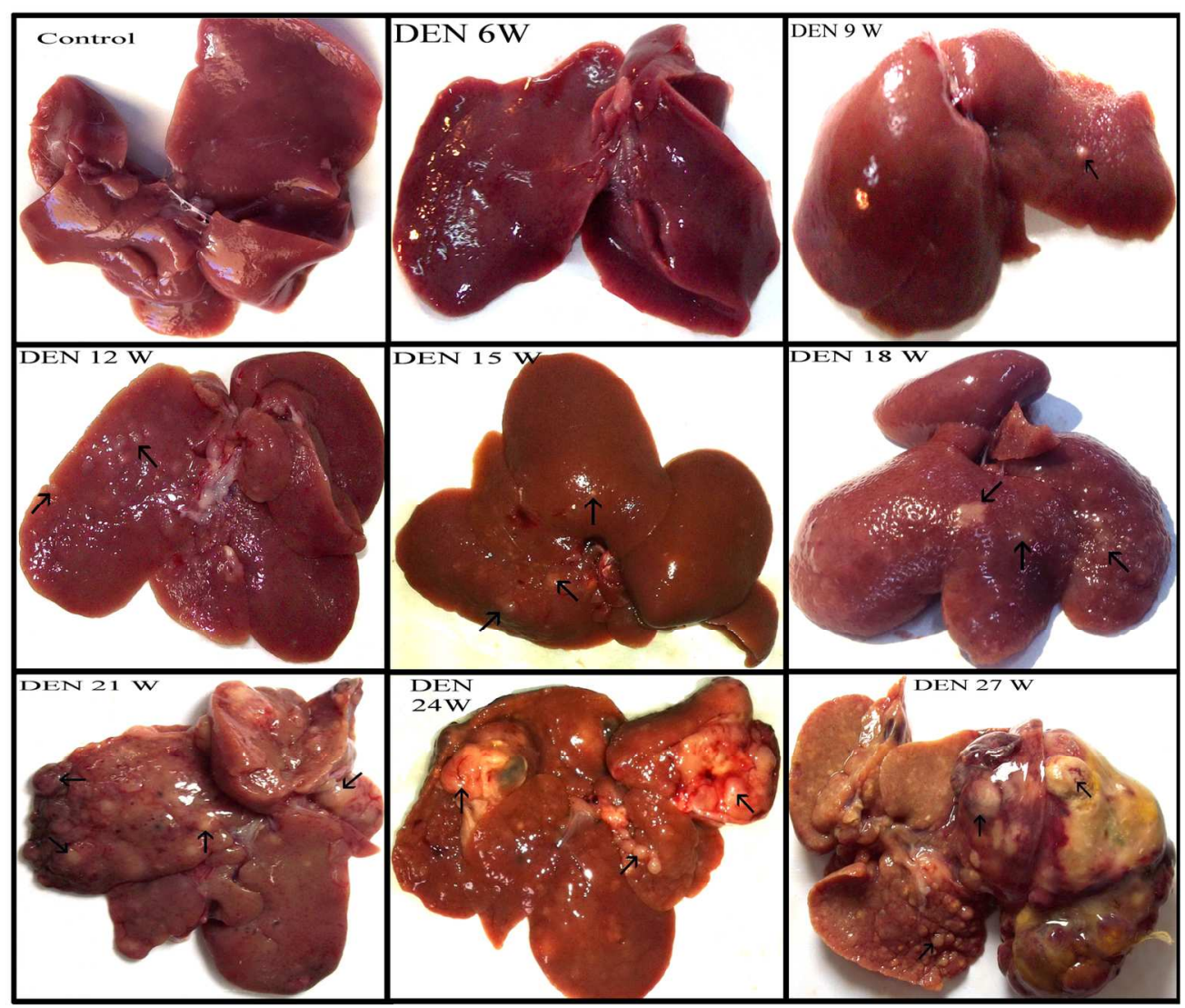

The macroscopic gross appearance of livers at the end of the experimental periods in the control and DEN administered groups (Arrows indicate nodules).

$143 \times 122 \mathrm{~mm}(300 \times 300 \mathrm{DPI})$ 


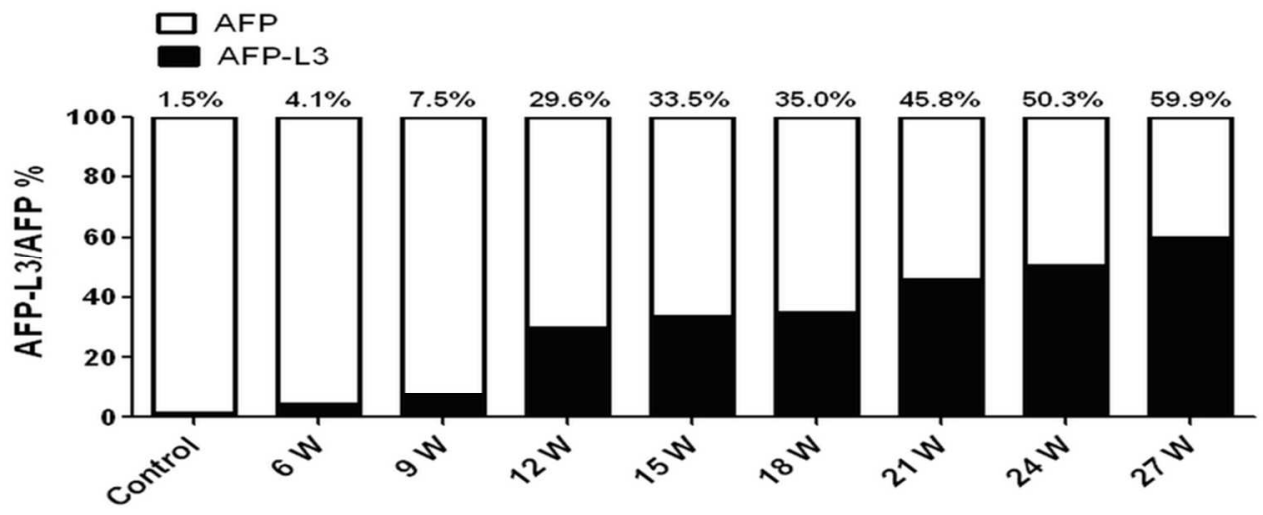

percentage of AFP-L3 (Lens culinaris agglutinin-reactive fraction of AFP) to total AFP at the end of the experimental periods in the control and DEN administered groups.

$89 \times 37 \mathrm{~mm}(300 \times 300 \mathrm{DPI})$ 

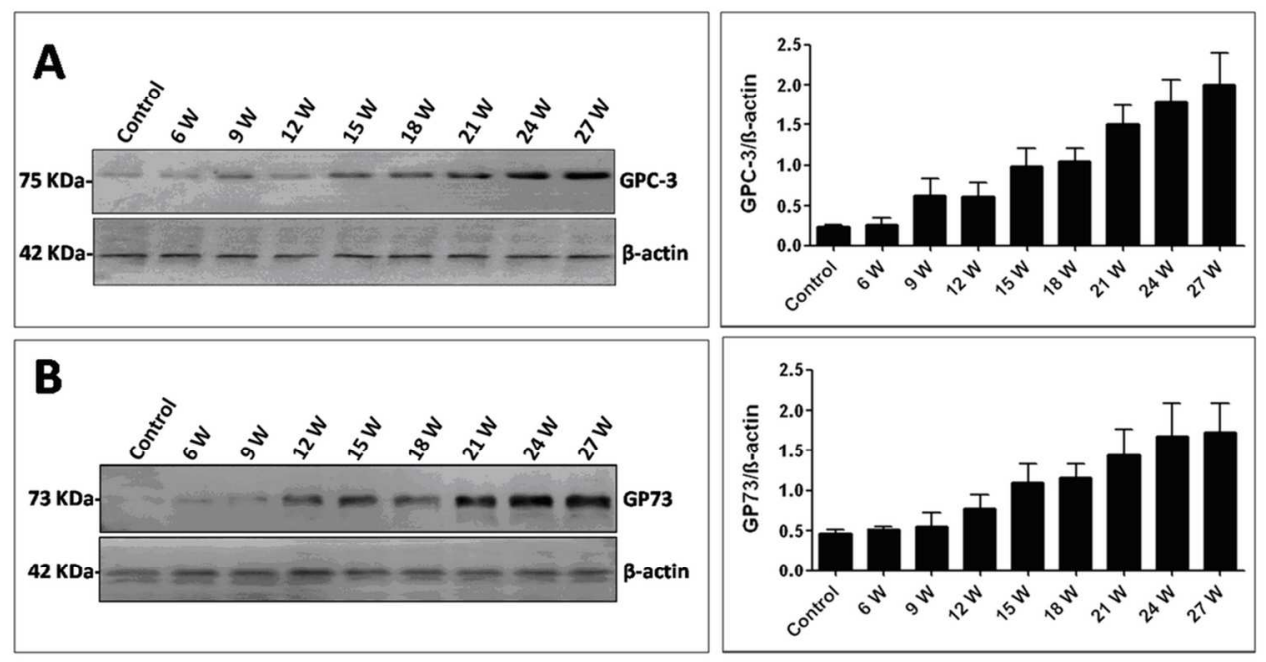

Western blot analysis of GPC3 (A) and GP73 (B) expressions in liver tissues at the end of experimental periods in the control and DEN administered groups.

$116 \times 62 \mathrm{~mm}(300 \times 300 \mathrm{DPI})$ 